Joachim Osiński

\title{
PRZEMIANY POLITYCZNE NA ISLANDII W WARUNKACH KRYZYSU BANKOWEGO I GOSPODARCZEGO
}

\section{Ustrój państwa}

Republika Islandii (Lýðveldið Íslands) jest państwem unitarnym położonym w północnej, subarktycznej części Oceanu Atlantyckiego. Terytorium państwa obejmuje $103300 \mathrm{~km}^{2}$, w tym $100600 \mathrm{~km}^{2}$ wyspa Islandia. Wprowadzenie w $1975 \mathrm{r}$. 200-milowej strefy wód terytorialnych w celu ochrony interesów ekonomicznych Islandii spowodowało objęcie we władanie obszaru morskiego liczącego $758000 \mathrm{~km}^{2}$, a więc ponadsiedmiokrotnie przewyższającego powierzchnię lądową państwa ${ }^{1}$.

Liczba ludności Republiki Islandii na dzień 1 grudnia 2010 r. wynosiła 318236 osób, co daje średnią gęstość zaludnienia 2,8 osoby na $\mathrm{km}^{2}$, najmniejszą w Europie ${ }^{2}$. Z tego w stolicy państwa Reykjaviku żyje 117505 mieszkańców (stan na 16 marca 2010 r.), a jeśli policzyć także suburbia, to liczba zamieszkujących ten region wyspy wyniosła 178301 osób, a więc ok. 63\% ogółu ludności. Inne duże, jak na warunki Islandii, miasta to: Akureyri (15102 mieszkańców), Keflavik (7574), Akranes (5188), Vestmannaeyjar (4594) i Selfoss (4339). Zdecydowana większość mieszkańców kraju (w 2008 r. - 89\%) przynależy do Islandzkiego Kościoła Ewangelicko-Augsburskiego, choć liczba wyznawców stopniowo maleje. Część ludności deklaruje się jako wyznawcy innych wyznań protestanckich $(3,3 \%)$ lub religii rzymskokatolickiej (1\%), część zaś określa się jako ateiści (4,2\%).

Po klęskach żywiołowych wieku XVIII - epidemii ospy w 1707 r., wybuchu wulkanów Öræfajökull w 1727 r. i Katla w 1755 r., potężnego trzęsienia ziemi w 1774 r. oraz ogromnej erupcji wulkanu Laki w latach 1783-1784 - liczba ludności wyspy

1 Por. J. Osiński, Wstęp, w: Konstytucja Republiki Islandii, tłumaczenie J. Osiński, Wyd. Sejmowe, Warszawa 2009, s. 3 .

2 Oficjalne najnowsze dane statystyczne dotyczące Islandii, patrz: www.statice.is, 14.04.2011. 
zdecydowanie spadła i w 1786 r. zamieszkiwało ją zaledwie 38400 osób. Jednak od tego momentu obserwujemy nieduży, ale stabilny wzrost populacji. W $1850 \mathrm{r}$. Islandię zamieszkiwało 59159 mieszkańców, a w 1901 r. - 79470, więc mniej więcej tyle samo, ile w XII-XIII w. W połowie lat 20. XX w. liczba mieszkańców przekroczyła 100 000. Średnia długość życia, podobnie jak w innych państwach regionu nordyckiego, jest bardzo wysoka i wynosi 77,9 lat dla mężczyzn oraz 81,5 lat dla kobiet ${ }^{3}$.

Konstytucja Republiki Islandii z 17 czerwca 1944 r. i praktyka ustrojowa minionego półwiecza uzasadniają traktowanie Islandii jako republiki z parlamentarno-gabinetową formą rządu i szczególną rolą ustrojową prezydenta ${ }^{4}$. Biorąc pod uwagę systematykę konstytucji, w której rozdział II w całości poświęcony został instytucji prezydenta, a jeszcze wcześniej, w rozdziale I w art. 2 wyjaśniona została logika konstrukcji zasady podziału władz w państwie, w której prezydent jest zarówno ważnym elementem władzy ustawodawczej, jak i dualnej władzy wykonawczej, uznaje się najczęściej, że w Republice Islandii występuje semiprezydencki system ustrojowy ${ }^{5}$. Pogląd taki przyjmuje wielu badaczy polskich i zagranicznych, w tym skandynawskich. Jednakże niektórzy z teoretyków skandynawskich, np. J. Nousiainen, akcentują rozbieżności pomiędzy różnymi czynnikami składającymi się na tzw. styl władzy (normy konstytucyjne, praktyka ustrojowa, styl sprawowania władzy, osobowość i zdolności sprawującego urząd czy kontekst sytuacyjny) ${ }^{6}$. Szczególny rozziew panuje między przepisami konstytucji i praktyką ustrojową. W moim przekonaniu nie wyciąga się zasadniczych wniosków z przepisu art. 1 konstytucji stanowiącego, że: „Islandia jest republiką z parlamentarną formą rządów”, a więc nie republiką prezydencką czy semiprezydencką ${ }^{7}$. Takie jednoznaczne stwierdzenie nakazuje daleko idącą ostrożność w formułowaniu ostatecznych ocen dotyczących ustroju państwa. Niewątpliwy jest tylko republikański charakter państwa.

Głową państwa jest prezydent wybierany w „wyborach powszechnych, bezpośrednich i tajnych, większością głosów (art. 5 konstytucji). Bierne prawo wyborcze przysługuje osobom, które ukończyły 35 lat i spełniają warunki uzyskania czynnego prawa wyborczego w wyborach parlamentarnych. Kandydat na prezydenta musi

3 Por. Nordisk statistisk årsbok 2002, Nordiska ministerrådet, Copenhagen 2002, s. 76-91.

4 Słusznie pisze na ten temat: G.H. Kristinsson, Between Form and Content: Semi-presidentialism in Iceland, w: Semi-presidentialism in Europe, red. R. Elgie, Cambridge University Press, Cambridge 1999.

5 Pomijam w tym miejscu dyskusję w polskiej literaturze na temat różnych wersji systemów mieszanych, w tym semiprezydenckiego, prezydencko-parlamentarnego czy premierowsko-prezydenckiego.

6 M.in. M. Grzybowski, A. Antoszewski czy D. Arter. Klasyczne jest w tej kwestii opracowanie M. Duvergera, A New Political System Model: Semi-Presidential Government, „European Journal of Political Research" 1980, Vol. 8, s. 165-187. Por. także: Parliamentary versus Presidential Government, ed. by A. Lijphart, New York 1992.

7 Pogląd taki prezentowałem wcześniej. Por. Prezydent Republiki Islandii, w: Prezydent w państwach wspótczesnych, red. J. Osiński, Oficyna Wydawnicza SGH, Warszawa 2009, s. 329-330. 
uzyskać podpisy wyrażające poparcie nie mniej niż 1500 wyborców, ale nie więcej niż 3000 wyborców, co stanowi podstawę rejestracji przez Narodową Komisję Wyborczą. Szczegółowe regulacje dotyczące wysuwania kandydatów, zbierania podpisów i organizacji wyborów zawarte są w ustawie wyborczej. Wybory organizowane są w jednej turze, przeważnie w czerwcu w roku upływającej kadencji, a wybranym zostaje kandydat, który otrzymał największą liczbę głosów, niekoniecznie ponad 50\%. (...) Kadencja prezydenta trwa 4 lata i rozpoczyna się 1 sierpnia w roku wyborów, a kończy 31 lipca po upływie 4 lat"8. Konstytucja Islandii nie ogranicza liczby kadencji, w których stanowisko prezydenta może piastować ta sama osoba. Aż czterech z pięciu prezydentów niepodległej Islandii piastowało ten urząd więcej niż dwie kadencje, w tym obecny prezydent Ólafur R. Grimsson piastujący urząd czwartą kadencję, która upływa 31 lipca 2012 r.

Prezydent Islandii jako głowa państwa reprezentuje je w stosunkach zarówno zewnętrznych, jak i wewnętrznych. Ma prawo zawierania umów i traktatów międzynarodowych z innymi państwami, jednak niektóre wymagają uprzedniej zgody Alpingi (art. 21 konstytucji). Urzędu prezydenta nie można łączyć z mandatem deputowanego ani $\mathrm{z}$ jakimikolwiek obowiązkami $\mathrm{w}$ instytucjach publicznych czy prywatnych. Prezydent wspólnie z parlamentem sprawuje władzę ustawodawczą oraz wraz z innymi organami rządu realizuje władzę wykonawczą (art. 2 konstytucji). Ten przepis i inne zawarte w konstytucji (np. art. 13 stanowiący, że „prezydent wykonuje swoją władzę poprzez ministrów”) nie pozwalają uznać prezydenta za szefa władzy wykonawczej. Należy podkreślić wpływ prezydenta na działalność ustawodawczą poprzez prawo inicjatywy ustawodawczej (art. 25 konstytucji) oraz prawo odmowy potwierdzenia uchwalonego w parlamencie projektu ustawy, czyli możliwość skorzystania z prawa weta (art. 26 konstytucji). Ma również prawo mianowania premiera i ministrów (art. 15 konstytucji), ale kieruje się przy tym wolą wyborców, mianując premierem lidera partii, która osiągnęła najlepszy wynik wyborczy lub kandydata wskazanego przez powstałą w Alpingi koalicję rządową. Akty prezydenta dotyczące mianowania ministrów muszą być kontrasygnowane przez premiera9 ${ }^{9}$.

Parlament Islandii - Alpingi - realizuje funkcję ustawodawczą, budżetowo-finansową, kontrolną i kreacyjną. Po reformie konstytucyjnej w $1991 \mathrm{r}$. Alpingi zmienił strukturę i jest parlamentem jednoizbowym składającym się z 63 deputowanych, wybieranych na 4 -letnią kadencję ${ }^{10}$. Wybory odbywają w kwietniu lub maju w roku

8 Konstytucja Republiki Islandii, op.cit., s. 19-20.

9 Szerzej na temat uprawnień prezydenta Islandii patrz: J. Osiński, Prezydent Republiki Islandii, w: Prezydent ..., op.cit., s. 342-353.

${ }^{10} \mathrm{Na}$ temat dwuizbowej struktury parlamentu islandzkiego patrz: B. Benediktsson, The Two Chambers of the Icelandic Althing, w: Legal Essays, red. F. Castberg, Universitetsforlaget, Oslo 1963, s. 394-410, a także 
kończącym kadencję. Prawo udziału w wyborach mają obywatele islandzcy, mężczyźni i kobiety po ukończeniu 18 lat. Taka granica wieku obowiązuje od 1984 r. Wybory są powszechne, równe, bezpośrednie tajne i proporcjonalne ${ }^{11}$.

W praktyce ustrojowej w odniesieniu do władzy wykonawczej Islandii występują obok siebie pojęcie „rząd”, rozumiane jako posiedzenie ministrów (ráðherra) odbywające się pod przewodnictwem premiera (forscetisráðherra), oraz pojęcie „Rada Państwa" (ríkisráð), używane konsekwentnie w tekście konstytucji, oznaczające posiedzenie ministrów wraz z premierem, lecz przebiegające pod przewodnictwem prezydenta Republiki. Pierwsze ma bardziej roboczy charakter, drugie zaś służy przede wszystkim jako ostatnia, często jedynie formalna faza prac nad rządowymi projektami ustaw, które przed skierowaniem do Alpingi powinny być zaaprobowane przez prezydenta. Ministrowie formalnie mianowani są przez prezydenta, w praktyce jednak w związku z tym, że muszą cieszyć się zaufaniem większości parlamentarnej, są proponowani przez premiera. Kandydatura samego premiera jest rezultatem ustaleń koalicyjnych, w trakcie których przewidziany jest udział przedstawiciela prezydenta. $\mathrm{W}$ praktyce ustrojowej państwa prezydent nigdy nie mianował premiera wbrew woli większości parlamentu, musi on bowiem cieszyć się zaufaniem Alpingi ${ }^{12}$.

\section{Sytuacja polityczna w przededniu kryzysu}

Ustrój polityczny państwa można określić jako stabilny, oparty na elementach demokracji konsensusowej, zakładających daleko idącą współpracę ugrupowań politycznych, w mniejszym zaś stopniu ich rywalizację. Rozwinięta kultura polityczna elit i społeczeństwa zdawała się być gwarantem stabilnego i demokratycznego rozwoju. Dla postronnego obserwatora życia politycznego na Islandii było ono uporządkowane i opierało na uznanych powszechnie przepisach prawa, a szczególnie $\mathrm{w}$ relacjach pomiędzy ugrupowaniami politycznymi na zakorzenionych głęboko zwyczajach politycznych. W rezultacie ewolucji sytuacji politycznej najważniejszym ugrupowaniem w początkach lat 90. była Partia Niepodległości (Sjálfstæðisflokkurinn), mająca za sobą długą tradycję konserwatywnego ugrupowania o narodowym charakterze. W kolejnych wyborach do islandzkiego parlamentu (Alpingi - Powszechne Zgromadzenie) od lat 50. uzyskiwała ona od 42,5\%

M. Grzybowski, Dwuizbowość w parlamentaryzmie państw nordyckich, w: Drugie izby parlamentu, Temida 2, red. E. Zwierzchowski, Białystok 1996, s. 213-240.

${ }^{11}$ Por. J. Osiński, Wstęp, w: Konstytucja Republiki Islandii, op.cit., s. 28-29.

12 Ibidem. 
głosów (w 1959 r.), do 27,2\% (w 1987 r.), średnio zaś ok. 36-38\% głosów wyborców. Jej przywódca w latach 90. i na początku XXI w., David Oddsson, był premierem rządu islandzkiego od 1991 r. do 2004 r., czyli przez 13 (nomen omen) lat. W ostatnich przed „katastrofą" wyborach w dniu 12 maja 2007 r. partia uzyskała 36,6\% głosów, co pozwoliło na objęcie 25 mandatów w 63-osobowym Alpingi oraz utworzenie rządu wspólnie z koalicją socjaldemokratyczną, określaną od wyborów z 8 maja 1999 r. jako Sojusz (Samfylkingin). Do wyborów parlamentarnych w 1995 r. była to Partia Socjaldemokratyczna (Alpýðuflokkurinn), która samodzielnie uczestniczyła w wyborach, uzyskując średnio ok. 14-15\% głosów. Wspomniane wybory do parlamentu w 2007 r. dały Sojuszowi 26,8\% głosów i 18 mandatów, sytuując go jako drugie największe ugrupowanie. Dotąd jednak tradycyjnym partnerem Partii Niepodległości w tworzeniu rządów była Partia Postępu (Framsóknarflokkurinn), która jednak przegrała omawiane wybory, uzyskując jedynie 11,7\% głosów i 7 mandatów. Trzecim ugrupowaniem została Lewica - Ruch Zielonych (Vinstrihreyfingin - grænt framboð), nowa partia powołana do życia 6 lutego $1999 \mathrm{r}$.

Na czele rządu koalicyjnego Partii Niepodległości i Sojuszu, powołanego po wyborach parlamentarnych 2007 r., ponownie stanął Geir H. Haarde, który w 2006 r. został przewodniczącym Partii Niepodległości i premierem, zastępując Halldóra Ásgrímssona. Rząd ten stał się symbolem kryzysu i bankructwa Islandii i, w rezultacie masowych protestów jesienią i zimą 2008 r. oraz opuszczenia koalicji rządowej przez Sojusz, został zmuszony do ustąpienia. Sojusz całą odpowiedzialność za kryzys bankowy i gospodarczy złożył na przedstawicieli Partii Niepodległości w rządzie i w parlamencie. Premier G.H. Haarde, w obliczu utraty popierającej go większości w Alpingi, został zmuszony 26 stycznia 2009 r. do złożenia wniosku o dymisję rządu na ręce prezydenta Republiki, Ólafura R. Grímssona. 1 lutego 2009 r. na stanowisko premiera rządu powołana została przez prezydenta Ó.R. Grímssona pani Jóhnna Sigurðardottir - pierwsza kobieta na tym stanowisku w historii Islandii. Stała się ona symbolem mozolnego wychodzenia społeczeństwa i gospodarki islandzkiej z katastrofy (jak wspomniałem, islandzki termin kreppa oznacza jednocześnie kryzys i katastrofę), choć nie wszystkie propozycje kierowanego przez nią rządu spotykały i spotykają się ze zrozumieniem społeczeństwa islandzkiego ${ }^{13}$.

${ }^{13}$ J. Sigurðardottir urodziła się 4 października 1942 r. w Reykjaviku. Ma dwóch dorosłych synów: Sigurðura Egilla (1972) i Daviða Steinara (1977). Legitymuje się średnim wykształceniem w dziedzinie handlu, pracowała m.in. jako stewardessa w Loftleiðir Icelandic Airlines, była członkiem zarządu Związków Zawodowych Pracowników Handlu oraz wiceprzewodniczącą Partii Socjaldemokratycznej. Jest deputowaną do parlamentu nieprzerwanie od 1978 r. Była członkiem wielu komisji stałych Alpingi, członkiem Prezydium Alpingi, a także ministrem spraw socjalnych od 8 lipca 1987 r. do 24 czerwca 1994 r. oraz od 24 maja 2007 r. do 1 lutego 2009 r., kiedy powołana została na stanowisko premiera. Jej oficjalną partnerką życiową jest Jónína Leósdóttir ur. 16 maja 1954 r. 
Partie islandzkie są organizacjami o raczej luźnej strukturze organizacyjnej, co odróżnia je od partii innych państw skandynawskich. Jednakże podkreśla się, iż mimo formalnie demokratycznego wewnętrznie charakteru przypominają niekiedy struktury oligarchiczne lub koterie koleżeńskie zdominowane przez lidera, a zmiany statutów dokonywane są znacznie częściej niż zmiany praktyki kierowania i funkcjonowania partiami ${ }^{14}$. Podstawy członkostwa w partiach islandzkich są niekiedy trudne do określenia, nie istnieje zwyczaj regularnego opłacania składek, a partie utrzymują się przede wszystkim z organizowanych loterii, środków finansowych przekazanych przez grupy interesu i firmy oraz z donacji osób fizycznych. Jednakże z drugiej strony wskazuje się, iż mimo niskiego stopnia instytucjonalizacji partie islandzkie znajdują się w bliskim kontakcie z wyborcami, o czym świadczy m.in. wysoka frekwencja wyborcza, niekiedy ponad $80 \%$, i aprobata społeczna wyrażana w badaniach opinii publicznej.

Wspomniana tendencja do oligarchizacji władzy w partiach (w przypadku Islandii szczególnie w odniesieniu do dwóch rządzących przez wiele lat ugrupowań: Partii Niepodległości i Partii Postępu) przeniosła się częściowo do systemu politycznego, na relacje pomiędzy osobami piastującymi w państwie różne odpowiedzialne funkcje. Sprzyjały temu działania przede wszystkim D. Oddssona, który otoczył się współpracownikami, a także powoływał na odpowiedzialne stanowiska osoby (G.H. Haarde, K. Gunnarsson, H. Gunnlaugsson, J.S. Gunnlaugsson i inni), które, podobnie jak on, były absolwentami Menntaskolinn w Reykjaviku (właściwie: Sigullum Schola Reykjavicencis), którą zresztą ukończyła większość premierów oraz znanych polityków i biznesmenów islandzkich ${ }^{15}$. Występowanie silnych osobistych więzów koleżeńskich pomiędzy absolwentami tej szkoły skupionymi wokół D. Oddssona spowodowało oczywistą erozję demokratycznych mechanizmów kontroli politycznej i prawnej zarówno w parlamencie, jak i w instytucjach powiązanych z rządem i w nim samym. Vilhjalmur Bjarnson, uznany ekonomista islandzki, analizując ten aspekt wśród przyczyn kryzysu, podkreślał, że bankructwo Islandii spowodowane zostało przez ok. 30 osób należących do ścisłej krajowej elity decyzyjnej bankowców i polityków ${ }^{16}$.

\footnotetext{
${ }^{14}$ Na podobne zjawisko w odniesieniu do partii politycznych w Szwecji, a szczególnie SAP, już wcześniej zwrócono uwagę w literaturze przedmiotu. Por. J. Teorell, Demokrati eller fåtalsvälde. Om besluttsfattande i partiorganisationer, Universitetsbiblioteket, Uppsala 1998, s. 25-37.

${ }^{15}$ Sigullum Schola Reykjavicencis jest najstarszą instytucją edukacyjną na wyspie. Powstała w $1056 \mathrm{r}$. i w znaczący sposób wpłynęła na rozwój wiedzy i oświaty, a także rozwój kultury materialnej i duchowej w całej historii Islandii.

${ }^{16}$ Por. R. Boyes, Meltdown Iceland. How the Global Financial Crisis Bankrupted an Entire Country, Bloomsbury, London-Berlin-New York 2009, s. 7.
} 


\section{Społeczeństwo islandzkie na progu kryzysu}

Islandczycy na początku XXI w. poczuli, że są bogaci i żyją w dobrobycie. Poczucie to kształtowane było przez zachodzące przemiany, które interpretowali w korzystny dla siebie sposób, w czym utwierdzały ich jednostronne przekazy medialne. W latach 90. przybyły na wyspę tysiące Polaków oraz obywateli innych państw Europy Środkowej i Wschodniej, którzy przejęli najcięższe i najbrudniejsze prace w rybołówstwie, przetwórstwie ryb i owoców morza, wyręczali miejscowych w budownictwie, opiekowali się chorymi i niedołężnymi, wykonywali prace na farmach, w stadninach koni i hodowlach owiec, pracowali w barach, kawiarniach i restauracjach. Miejscowi, zwolnieni z tych podstawowych obowiązków, poczuli się „stworzeni do rzeczy wielkich”. Rybacy, marynarze, osoby zatrudnione przy przetwórstwie owoców morza, szoferzy, farmerzy i pracownicy socjalni zostawali biznesmenami, bankowcami i finansistami.

Wiarę w to, że „Islandczyk potrafi” kształtowali i podtrzymywali liczni, przybyli głównie z Wielkiej Brytanii, USA i Danii, specjaliści od finansów i bankowości, zatrudniani w nowo otwieranych filiach i oddziałach międzynarodowych banków. Już w 1990 r. na Islandii stosunek zatrudnionych w sektorze bankowym do ogółu zatrudnionych w gospodarce był najwyższy w Skandynawii i zbliżony do tego w Szwajcarii $^{17}$. Islandczycy chętnie słuchali polityków jedynie słusznej formacji neoliberalnej (głównie polityków z rządzącej Partii Niepodległości, która kontrolowała także telewizję publiczną), wmawiających im, że pora korzystać z owoców wielu lat ciężkiej pracy, zaprzestać wyrzeczeń, czas wybudować dom, kupić lepszy samochód, wyjechać na zimowy wypoczynek do Tajlandii. Oczywiście wszystko to na kredyt, powszechnie i dla wszystkich dostępny. Jednak niektóre dane ekonomiczne zaczęły być niepokojące. Zadłużenie gospodarstw domowych w 2008 r. z powodu zaciągnięcia kredytów osiągnęło 213\% ich rocznych dochodów po opodatkowaniu (w Wielkiej Brytanii ok. 169\%, w USA zaś 140\%) ${ }^{18}$. Zadłużenie zagraniczne Islandii w 2008 r. szacowano na ok. 50 mld euro, z czego $80 \%$ przypadało na sektor bankowy. W przeliczeniu na jednego mieszkańca wyspy dawało to ok. 160 tys. euro, czyli było bardzo wysokie.

Sprywatyzowana i zderegulowana gospodarka, w tym banki, miała się „doskonale", o czym zapewniał ówczesny premier rządu, symbol neoliberalnej nowoczesności i megalomanii, D. Oddsson, który określał siebie skromnie jako „Margaret Thatcher gospodarek północy”, a który dodatkowo po zakończeniu kariery politycznej

17 Por. Á. Jónsson, Why Iceland? How one of the World's Smallest Countries Become the Meltdown's Biggest Casualty, McGraw-Hill, New York-Chicago 2009, s. 27.

18 Kreppanomics, komentarz „The Economist” 09.10.2008. 
został na nieszczęście w 2004 r. szefem banku centralnego. To jego fascynacji prywatyzacją i deregulacją Islandia zawdzięcza brak skutecznego nadzoru instytucjonalnego nad bankami (mimo istnienia od 1998 r. Islandzkiej Komisji Nadzoru Finansowego - FME, która okazała się niekompetentna i nie była w stanie wyciągnąć wniosków z negatywnych symptomów pojawiających się w systemie bankowym już w końcu 2006 r.) i polityką pieniężną, a także brak ustawy regulującej szczególny status Banku Centralnego Islandii, która wyposażałaby go w odpowiednie instrumenty oddziaływania na system bankowy, zdominowany przez podmioty prywatne. Stosowna ustawa została opracowana przy udziale ekspertów zagranicznych i uchwalona przez Alpingi dopiero 26 lutego 2009 r., wprowadzając m.in. nowy tryb powoływania prezesa banku centralnego, zastępcy prezesa, zmniejszając liczbę członków zarządu oraz powołując nowe struktury administracyjne banku, w tym Komitet Polityki Pieniężnej, którego dotąd nie było.

Społeczeństwo islandzkie funkcjonujące według starych tradycyjnych wzorców uległo jednak w okresie ostatnich 20 lat istotnym przeobrażeniom, niewidocznym być może dla zwykłych obywateli. Wbrew wysokim pozycjom w rankingach Transparenty International Islandczycy nie zauważali lub nie chcieli dostrzec pogłębiających się patologicznych, korupcjogennych oraz oligarchicznych układów i mechanizmów na styku polityki i biznesu w swoim kraju. Utracili zbiorowy, społeczny instynkt samozachowawczy w pogoni za kształtowaniem swojego własnego, prywatnego dobrobytu w sytuacji powszechnego dostępu do łatwego pieniądza, na który zielone światło dali neoliberalni alchemicy od finansów, związani z realnie rządzącymi polityką i gospodarką Islandii „rodzinami”.

Program prywatyzacji gospodarki, w tym przede wszystkim banków, zapoczątkowany przez rząd pod kierownictwem D. Oddssona w latach 90., i czynniki tj. powszechna dostępność osób fizycznych i prawnych do kredytów spowodowana konkurencją pomiędzy bankami oraz ekspansja zewnętrzna islandzkich banków ze względu na zbyt płytki rynek wewnętrzny, rozpoczęły tworzenie na Islandii nowego systemu bankowego. Rozwój banków „był wspomagany islandzkim członkostwem w Europejskiej Strefie Ekonomicznej (European Economic Area - EEA). Islandia praktycznie stworzyła nowy system finansowy, w tym nadzorczy, adaptując do siebie dyrektywy Unii Europejskiej. Banki islandzkie objęto wspólnym europejskim paszportem, który oznaczał, że licencje bankowe wydane w Islandii dla islandzkich instytucji finansowych dotyczyły także wszystkich krajów EEA. Europejskie ramy regulacyjne dawały islandzkim bankom tę samą operacyjną swobodę w całej strefie EEA, jaką miały na terenie Islandii”' ${ }^{\prime 9}$. Niebagatelne znaczenie miały także dochody

${ }^{19}$ L. Kurkliński, Bankowość islandzka - bankructwo systemu?, w: Międzynarodowe bankructwa $i$ afery bankowe, red. P. Masiukiewicz, Oficyna Wydawnicza SGH, Warszawa 2010, s. 235. 
budżetu państwa pochodzące z podatków od banków, a także przychylne ratingi kredytowe, jakimi obdarzano banki islandzkie. Dlatego trzy największe z nich posiadające 85\% aktywów islandzkiego systemu bankowego - Landsbanki, Kaupthing i Glitnir - rozpoczęły dynamiczną ekspansję międzynarodową przede wszystkim na rynek brytyjski i skandynawski, ale nie tylko.

Procesy prywatyzacji przyspieszone w latach 90. i połączone z deregulacją gospodarki (szczególnie rynku finansowego), a z drugiej strony hasła o końcu zaciskania pasa przez Islandczyków i zasłużonym korzystaniu z osiągniętego poziomu rozwoju służyły w rzeczywistości wąskiej grupie 14 rodzin - tzw. islandzkiej Ośmiornicy ${ }^{20}$. Ich członkowie w niebezpieczny sposób, poza wszelką demokratyczna kontrolą, a niekiedy w świetle jupiterów i zgodnie z prawem, które tworzono na ich „zamówienie”, przejmowali kolejne fragmenty islandzkiej gospodarki i prywatyzowali przestrzeń publiczną, wykorzystując instytucje państwowe do dalszej ekspansji. Doszło z czasem do patologicznego połączenia potęgi i wpływów gospodarczych poszczególnych klanów z wpływami i znaczeniem politycznym. Prowadziło to do wykorzystywania przez osoby piastujące stanowiska premierów, ministrów i deputowanych swoich pozycji do umożliwiania związanym $\mathrm{z}$ nimi więzami rodzinnymi osobom przejmowania pakietów kontrolnych kolejnych prywatyzowanych firm oraz zakładania nowych firm i przedsiębiorstw będących pod „ochroną” instytucji państwowych. W zamian członkowie zarządów banków, szefowie wielkich firm transportowych i ubezpieczeniowych oraz większościowi udziałowcy wspierali poszczególnych polityków. Tego rodzaju symbioza występowała przede wszystkim w obrębie Partii Niepodległości, która w związku z tym niepodzielnie panowała w życiu publicznym Islandii.

Ze wspomnianych 14 rodzin, dwie odgrywały w życiu politycznym i gospodarczym Islandii rolę szczególną: rodzina Engey i rodzina H. Ben. Pierwszą, biorącą nazwę od maleńkiej wysepki położonej na wprost Reykjaviku, stworzył Bjarni Benediktsson - premier Islandii w latach 1963-1970 i przewodniczący Partii Niepodległości (obecnie od 2009 r. partią kieruje jego wnuk, również Bjarni Benediktsson). Rodzina przez lata kontrolowała nie tylko wspomnianą firmę transportową Eimskip i linię lotniczą Icelandair, ale także Islandsbanki, koncern paliwowy NI oraz powołaną przez Sveina Benediktssona, który był bratem premiera, znaczącą firmę ubezpieczeniową Sjova. W latach 70. nikt nie mógł liczyć na przychylność rządu, jeśli nie „odwdzięczył” się rodzinie ${ }^{21}$.

${ }^{20}$ Nazwa nie jest przypadkowa i nie ma charakteru naśladowczego, bowiem w rzeczywistości powstawanie „klanowego imperium” rozpoczęło się od stopniowego przejmowania wewnętrznych sieci transportowych na wyspie oraz sieci transportu do i z Islandii. Zasadniczą rolę odegrała w tym procesie firma żeglugowa Eimskip. Szerzej por. R. Boyes, Meltdown Island. How the Global Financial Crisis Bankrupted an Entire Country, Bloomsbury, London-Berlin-New York 2009, s. 33-36.

${ }^{21}$ Por. ibidem, s. 35. 
Nazwa drugiej rodziny - H. Ben - pochodzi od Hallgrimura Benediktssona. Z niej wywodził się premier Islandii w latach 1974-1978, Geir Hallgrimsson, który także przewodził Partii Niepodległości, będącej polityczną osłoną dla ekspansji ekonomicznej rodziny (Shell Iceland, monopol w handlu samochodami, fabryka słodyczy, nieruchomości ${ }^{22}$. Były to grupy nieformalne, które niekoniecznie były właścicielami dużej liczby firm, ale poprzez swoje koneksje polityczne mogły zapewnić, np. firmom połowowym czy przetwórniom ryb, pewien stopień ochrony przed konkurencją lub urzędami państwowymi. Jednocześnie kontrolowały wszystkie przejawy aktywności gospodarczej, która mogła przynosić duże dochody, np. handel kwotami połowu ryb wprowadzonymi przez rząd w celu ochrony łowisk (rybołówstwo tworzy ok. $12-14 \%$ PKB Islandii). Mimo że pod koniec lat 80 . metody działania rodzin uległy zmianie, ucywilizowały się, to jednak ścisłe związki pomiędzy aktywnością i znaczeniem politycznym a przedsięwzięciami gospodarczymi, szczególnie w odniesieniu do elity i działaczy Partii Niepodległości, pozostały.

\section{System bankowy Islandii, jego rozwój i rozpad}

Pierwsze banki spółdzielcze, mające charakter kas oszczędnościowo-pożyczkowych, zaczęły rozwijać się na Islandii w XIX w. Taki charakter miał Landsbanki (Bank Krajowy) założony w 1886 r., który w 1918 r., w momencie przyznania szerokiej autonomii wyspie i zawarciu unii personalnej w Danią, uzyskał prawo emisji banknotów. Korzystał z tego prawa do 1961 r., kiedy powołano do życia Bank Centralny Islandii (Sedlabanki), który uzyskał przywilej emisji pieniądza. Po sprywatyzowaniu banku, w latach 1997-2003, zarząd Landsbanki w większym stopniu zainteresował się aktywnością poza Islandią. W latach 2006-2008 otworzył oddziały m.in. w Helsinkach, Oslo, Londynie i Amsterdamie, a w dwóch ostatnich oferował obywatelom Wielkiej Brytanii i Holandii w ramach IceSave, poprzez bankowe usługi internetowe, wysokooprocentowane rachunki oszczędnościowe i udziały w funduszach hedgingowych. W rezultacie skutecznie przeprowadzonej kampanii reklamowej udało się w ciągu 5 miesięcy nakłonić ponad 300 tys. Brytyjczyków do powierzenia bankowi (IceSave działał zgodnie z literą prawa brytyjskiego, jako oddział Landsbanki) depozytów o wartości ponad 5 mld euro oraz ponad 125 tys. Holendrów, którzy przekazali IceSave 1,7 mld euro ${ }^{23}$. Upadek IceSave wskutek kryzysu płynności na rynkach

\footnotetext{
22 Ibidem, s. 35-36.

${ }^{23}$ Por. T. Brogger, H.K. Einarsdottir, Iceland Reaches Deposit Accord With U.K., „Bloomberg” 11.10.2008.
} 
finansowych, a następnie niewypłacalności wynikłej z podejmowania nadmiernego ryzyka i złego zarządzanie funduszami, ma swoje skutki do dnia dzisiejszego dla relacji Islandii z obu wspomnianymi państwami.

Kaupthing Bank był stosunkowo „młodą” instytucją finansową, powołaną do życia w 1982 r. przez 8 osób, i początkowo zajmował się doradztwem i usługami maklerskimi. W swej działalności skupiał się na obrocie papierami wartościowymi i ofercie asset management. Kaupthing był jedną z pięciu instytucji finansowych, które w 1986 r. powołały do życia islandzką giełdę, od 1996 r. zaś jeszcze jako firma brokerska rozpoczął swoją aktywność na rynkach międzynarodowych, obsługując głównie Islandczyków zamieszkałych w Europie Zachodniej przez firmę-córkę założoną w Luksemburgu ${ }^{24}$. Dopiero w 1997 r. uzyskał licencję banku inwestycyjnego, a w 2002 r. pełną licencję banku komercyjnego (łączył więc funkcje banku komercyjnego i banku inwestycyjnego). Po fuzji z mającym wieloletnią tradycję sięgającą 1930 r. i dobrą renomę Bankiem Rolnym Islandii (Bunadarbanki) został największym bankiem Islandii ${ }^{25}$. Nie bez znaczenia był fakt, iż na jego czele od $1997 \mathrm{r}$. stał Sigurdur Einarsson, który prezentował obiecujące plany ekspansji międzynarodowej. Jednocześnie w praktyce okazała się ona jedną z głównych przyczyn jego upadku. Od 2007 r. Kaupthing Bank rozpoczął kampanię marketingową swojego najnowszego produktu internetowego, Kaupthing Edge, będącego odpowiednikiem IceSave prowadzonego przez Landsbanki, dostępnego w Wielkiej Brytanii, Belgii, Norwegii, Szwecji, Finlandii, Niemczech, Luksemburgu, Austrii i Szwajcarii. Działający na prawach oddziału banku Kaupthing Edge oferował dwa rodzaje depozytów: rachunek oszczędnościowy i lokaty o stałym oprocentowaniu. „Zasadniczym celem było znalezienie dobrego i zasobnego źródła finansowania poprzez propozycję depozytową,

\footnotetext{
${ }^{24}$ Szczegółowo o wydarzeniach i osobach (Björgólfur Gudmundsson i Björgólfur Thor Björgólfsson - pierwszy był 249 na liście najbogatszych ludzi według czasopisma „Forbes” w 2007 r., drugi zaś na 799 miejscu), które przyczyniły się do nadzwyczajnego wzrostu znaczenia Kaupthing, ale także do jego upadku i bankructwa całego systemu bankowego Islandii, pisze Ásgeir Jónsson, op.cit., s. 44-50.

${ }^{25}$ Islandzki system bankowy czerpał wiele rozwiązań z USA, w tym rozwiązań prawnych. Przykładem była ustawa Alpingi, zawierająca podobne ograniczenia dla rozwoju banków, jak amerykańska ustawa z 1933 r. Glass-Steagall Act, która wprowadzała m.in. separację bankowości komercyjnej (detalicznej) i inwestycyjnej, bądź, mówiąc inaczej, zakazywała bankom komercyjnym (detalicznym) powoływania i posiadania innych firm finansowych, w tym ubezpieczeniowych czy private equity. Uchwalenie przez Kongres USA w 1999 r. ustawy Gramm-Leach-Bliley Act, określanej ustawą o modernizacji usług finansowych, wprowadziło znaczącą deregulację na rynku usług finansowych, bankowych i ubezpieczeniowych oraz rynku papierów wartościowych. Od tej regulacji banki komercyjne, banki inwestycyjne i firmy ubezpieczeniowe za pomocą firm specjalnego przeznaczenia (tzw. SPC, SPV, SIV) w istocie swej instytucji parabankowych, mogły w pełni podjąć ekspansję na rynkach kapitałowych, w tym kredytów hipotecznych. W ślad za USA, także Islandia wprowadziła podobne przepisy deregulacyjne, co umożliwiło ekspansję banków islandzkich na rynki europejskie i połączenie obu rodzajów bankowości, czego Kaupthing był najlepszym przykładem od 2002 r. Szerzej patrz: B. Samojlik, Kryzys finansowy: źródła, skutki, kierunki naprawy, w: Nauki społeczne wobec kryzysu na rynkach finansowych, red. J. Osiński, S. Sztaba, Oficyna Wydawnicza SGH, Warszawa 2009, s. $62-64$.
} 


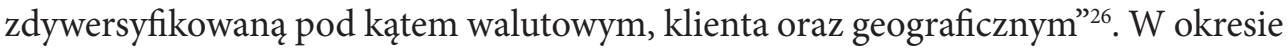
sześciu miesięcy do czerwca 2008 r. zebrano ponad 3,1 mld euro ${ }^{27}$.

Trzeci z banków - Glitnir Bank, w islandzkim systemie bankowym był instytucją przejściową. Jego nazwa powstała od nazwy istniejącego dotąd banku prywatnego - Islandsbanki, który na początku lat 90 . XX w. był jedynym liczącym się prywatnym bankiem na Islandii. Glitnir powstał w $1990 \mathrm{r}$. z połączenia trzech mniejszych banków prywatnych: Banku Związkowego (Alpydubanki), Banku Handlowego (Verzlunarbanki) i Banku Przemysłowego (Idnadarbanki) oraz postawionego w stan upadłości banku państwowego - Banku Rybołówstwa (Utvegsbanki). W Islandii oprócz Glitnir istniały banki państwowe: Bank Rolny Islandii (Bunadarbanki), Bank Krajowy (Landsbanki) oraz, powołany przez państwo w 1998 r. na gruncie sieci różnych państwowych funduszy inwestycyjnych, Przemysłowy Bank Inwestycyjny (Fjárfestinga Banki Atvinnulífsins). Te cztery banki miały 97\% udziałów w całym islandzkim systemie finansowym, który w końcu lat 90. stanowił 7,3\% produktu krajowego brutto, Islandsbanki (Glitnir od 2000 r.) zaś był największym bankiem komercyjnym (detalicznym), choć ze względu na wspomnianą deregulację działalności instytucji finansowych, szybko stał się także bankiem inwestycyjnym, szczególnie obecnym w sektorach gospodarki morskiej, energetyki i przemysłu spożywczego ${ }^{28}$. Po swojej „przygodzie” z międzynarodowym rynkiem finansowym, już państwowy Glitnir Bank od lutego 2009 r. powrócił do swojej pierwotnej nazwy - Islandsbanki.

W 2003 r. Glitnir Bank osiągnął zysk netto w wysokości ponad $67 \mathrm{mln}$ euro, zwiększając go w 2004 r. w niespotykanym tempie do 137 mln euro, w 2005 r. do ponad 242 mln euro, a w 2006 r., kiedy nastąpiło apogeum, zysk netto banku wyniósł ponad $436 \mathrm{mln}$ euro, co - biorąc pod uwagę kraj pochodzenia i inne okoliczności - mogło wzbudzać niechęć czy zazdrość w części międzynarodowego środowiska finansowego brytyjskiego czy skandynawskiego ${ }^{29}$. Ten subiektywny element

26 L. Kurkliński, Bankowość islandzka - bankructwo systemu?, op.cit., s. 241-242.

27 Por. Kaupthing Bank Company Profile, Reykjavik, September 2008.

28 Por. Á. Jansson, Why Iceland?, op.cit., s. 40-42. Po przejęciu banku przez państwo w lutym 2009 r. powrócono do jego pierwotnej nazwy, która obowiązuje obecnie - Islandsbanki. Tego rodzaju organizacje finansowe określa się współcześnie na Islandii terminem „banki gejzerowe” - wybuchają bardzo efektownie, ale równie szybko kończy się ich żywot.

${ }^{29}$ W części prasy skandynawskiej niechętnej ekspansji islandzkich banków ze względu na nierówne warunki konkurencji - przepisy prawne i nadzór finansowy nad rodzimymi bankami, szczególnie w Szwecji czy Norwegii, były znacznie bardziej restrykcyjne (np. ograniczenia w łączeniu bankowości komercyjnej „detalicznej” z inwestycyjną, zakaz tworzenia przez banki detaliczne spółek parabankowych, ograniczenia „lewarowania”, które w Glitnir Banku sięgało proporcji 1:50 itd.) - pojawiały się wyraźne sugestie co do ograniczenia obecności islandzkich banków i instytucji finansowych w Szwecji. Przykładowo, już w 2002 r. po złożeniu oferty kupna przez Kaupthing Bank niewielkiego szwedzkiego banku inwestycyjnego JP Nordiska tytuł w jednej z „bulwarówek” sztokholmskich głosił: Islandczycy wracajcie do domu, to nie jest targ rybny. 
odczuwalnej konkurencji, ale także zawiści czy zazdrości środowiska finansistów wobec islandzkich nuworyszy, pojawia się i powtarza często w końcu 2008 r. wśród wymienianych subiektywnych przyczyn utraty płynności przez wszystkie trzy wspomniane banki islandzkie. Jednakże niekiedy niektórzy z autorów wywodzący się ze środowiska bankowców, poszukując usprawiedliwienia dla swojego braku wiedzy, pazerności, chciwości i podejmowania nadmiernego ryzyka, starają się uczynić z tych subiektywnych przyczyn, przyczyny najważniejsze ${ }^{30}$.

Symptomy nadciągającego kryzysu zaobserwowano już w 2006r. „W ocenach analityków zaczęła pojawiać się nieufność. Pociągnęło to za sobą wzrost marż na rynku pieniężnym, co znacząco podrożyło koszty finansowania. Niestety, był to szok dla banków, przyzwyczajonych do gładkiego znajdowania źródeł finansowania swojej działalności na rynku międzynarodowym. Krytyczne uwagi dotyczyły: tempa wzrostu, apetytu na ryzyko, niskich wskaźników depozytowych, wysokiego uzależnienia od rynku pieniężnego, krosowych struktur własności oraz braku wystarczającej transparentności” ${ }^{31}$. W lutym 2006 r. z inicjatywy premiera G.H. Haardego zawarto porozumienie pomiędzy rządem islandzkim (szczególnie Ministerstwem Finansów i Ministerstwem Gospodarki) oraz Bankiem Centralnym Islandii i Komisją Nadzoru Finansowego (FME) zmierzające do koordynacji działań w celu umocnienia stabilizacji finansowej państwa oraz przedsięwzięć prowadzących do systemowego wzmocnienia trzech największych banków islandzkich i „zmuszenia” ich do modernizacji, a szczególnie większej otwartości informacyjnej, zmniejszenia wzajemnych powiązań własnościowych, poprawy płynności i wskaźników kapitałowych, w tym zwiększenia udziału depozytów w ich bilansach. Do podobnych działań zachęcały także agencje ratingowe, mimo że wcześniej np. agencja Moody’s wielokrotnie podnosiła rating Kaupthing Banku. W przeszłości właśnie ze względu na wysokie oceny wiarygodności kredytowej Islandii i pochodzących stamtąd instytucji finansowych wystawiane przez agencje ratingowe chętnie inwestowano w tym państwie w rozwój energetyki, hutnictwa aluminium czy sieci transportowych, szczególnie morskich.

Neoliberalna wiara w to, że rynki finansowe charakteryzuje zdolność do samoregulacji dominowała także wśród elity bankowej Islandii. Skutkowało to naciskami na rząd oraz instytucję nadzoru finansowego (FME), aby to banki same oceniały skalę podejmowanego ryzyka i same decydowały o tym, jak duży kapitał jest im potrzebny na pokrycie ewentualnych strat. Wszelkim próbom regulacji prawnej tej kwestii przeciwstawiał się ówczesny premier D. Oddsson, autor sformułowanego

30 Takie wrażenie można odnieść po lekturze cytowanej wyżej pracy Ásgeira Jónssona, który był szefem Działu Badań i Doradców Ekonomicznych Kaupthing Bank, a wcześniej - wykładowcą finansów międzynarodowych i bankowości na Uniwersytecie w Reykjaviku.

${ }^{31}$ L. Kurkliński, Bankowość islandzka - bankructwo systemu?, op.cit., s. 249. 
w końcu lat 90. projektu prywatyzacji gospodarki islandzkiej, w tym także prywatyzacji sektora bankowego. Był on wspierany politycznie przez Partię Niepodległości, a medialnie i gospodarczo przez stojący za nim $\mathrm{klan}^{32}$. Skrajna deregulacja występowała także w systemach bankowych innych państw (szczególnie USA) i Islandia, za sprawą mającego poczucie misji premiera D. Oddssona, podążała tą samą drogą, niestety ze znacznie gorszymi skutkami. „Ex post okazało się, że banki działały wbrew swoim interesom, ponieważ właśnie zablokowanie przez nie inicjatyw instytucji nadzorczych, by objąć sprawozdawczością finansową transakcje pozabilansowe banków, stało się główną przyczyną kryzysu zaufania w amerykańskim systemie bankowym, co sprawiło, że rynek pożyczek międzybankowych praktycznie zamarl”33.

Rykoszetem odbiło się to na bankach islandzkich, które nie mogły znaleźć, ani w Europie, ani za Atlantykiem, finansowania na wykup wyemitowanych obligacji, których termin zapadał w połowie października $2008 \mathrm{r}$. Wobec braku transparentności transakcji pozabilansowych banków, podejrzewały one siebie nawzajem o ukrywanie nietrafionych przedsięwzięć finansowych w różnych spółkach celowych (specjalnego przeznaczenia). Na wszelki więc wypadek dla utrzymania wyższego kapitału $\mathrm{w}$ razie strat własnych przestały sobie wzajemnie pożyczać i wstrzymały swoją aktywność na rynku międzybankowym. Problem nie polegał więc na braku płynności, ale przede wszystkim na niedostatku wzajemnego zaufania ${ }^{34}$. Ogłoszenie 15 września 2008 r. bankructwa Lehman Brothers uruchomiło procesy przyspieszające przekształcanie się kryzysu płynności, spowodowanego niedostatkiem zaufania między instytucjami rynków finansowych, w kryzys niewypłacalności. Wraz z przełomem września i października $2008 \mathrm{r}$. uderzył on w dobrze prosperującą wyspę na Atlantyku, na której rybacy i farmerzy postanowili zostać bankierami.

\section{Wpływ kryzysu bankowego na zmiany polityczne}

Wydarzenia na Islandii uległy znacznemu przyspieszeniu w końcu września 2008 r. Efekt domina rozpoczęły problemy Glitnir Banku, który w 2003 r. wyemitował obligacje 5-letnie na sumę ponad $600 \mathrm{mln}$ euro, a $\mathrm{z}$ uzyskanych funduszy

\footnotetext{
32 Program prywatyzacji, którego beneficjentami były przede wszystkim osoby i firmy związane z dwoma największymi rodzinami, formalnie nadzorowany przez rząd i powołany przezeń Islandzki Komitet ds. Prywatyzacji, realizowany był niewłaściwie, często niezgodnie z prawem i w oparciu o klanowe układy, na co zwracano uwagę także przy prywatyzacji trzech największych banków, a szczególnie w 2002 r. przy okazji częściowo publicznej prywatyzacji Landsbanki. Por. R. Boyes, Meltdown Iceland.., op.cit., s. 54-55.

${ }^{33}$ A. Sławiński, Przyczyny globalnego kryzysu bankowego, w: Nauki społeczne ..., op.cit., s. 45.

${ }^{34}$ Bernanke przegrywa $z$ kryzysem, „The Wall Street Journal Polska” 21.10.2008, s. 6.
} 
finansowano w kolejnych latach m.in. międzynarodową ekspansję banku. Termin ich wykupu przypadał na dzień 15 października 2008 r. Zarząd Glitnir Banku nie był przygotowany do nowej sytuacji (m.in. upadek Lehman Brothers) i nie posiadał wystarczającej ilości gotówki na spłatę zobowiązań. Dodatkowo w podobnym terminie zapadalności Glitnir powinien zwrócić pożyczkę w wysokości $150 \mathrm{mln}$ euro wraz z odsetkami niemieckiemu Bayerische Landesbank, który 24 września 2008 r. odmówił przedłużenia terminu spłaty i zażądał terminowego uregulowania zobowiązania ${ }^{35}$. W dniach 27 i 28 września najważniejsi politycy z premierem na czele, prezesi trzech największych islandzkich banków, prezes banku centralnego, kierownictwo Komisji Nadzoru Finansowego w trakcie weekendowych roboczych posiedzeń w siedzibie FME zdecydowali o połączeniu Glitnir z Landsbanki oraz przejęciu przez rząd 75\% udziałów o wartości 600 mln euro w Glitnir Bank ${ }^{36}$. Decyzja ta spowodowała w kolejnych dniach gwałtowny spadek cen akcji banku, obniżenie ratingu praktycznie wszystkich najważniejszych banków islandzkich oraz wyraźny spadek kursu korony.

Informacje te wywołały niepokój Brytyjczyków mających swoje depozyty w IceSave, w oddziale bankowości internetowej Landsbanki. Do piątku 3 października klienci wypłacili ponad $200 \mathrm{mln}$ funtów, a w ciągu kolejnych 24 godzin, korzystając z możliwości internetowego dostępu do kont, przelali z rachunków IceSave kolejne $300 \mathrm{mln}$ funtów. W zaistniałej sytuacji władze brytyjskiego nadzoru finansowego (FSA), mając w pamięci podobne problemy z bankiem Northern Rock, zażądały od Landsbanki transferu $400 \mathrm{mln}$ funtów bezpośrednio do Banku Anglii na poczet przyszłych wypłat z kont IceSave. Należy dodać, że znaczne zwiększenie wypłat nie dotyczyło w tym tygodniu (między 29 września i 5 października 2008 r.) jeszcze Kaupthing Edge, w którym depozyty klientów objęte były brytyjską gwarancją depozytów, podobną do gwarancji amerykańskiej FDIC ${ }^{37}$.

Wystąpienie premiera G.H. Haardego 2 października zawierało elementy ostrożnego optymizmu i słowa pokrzepienia wskazujące na to, iż rząd, współpracując z bankami, panuje nad sytuacją. Jednak wydarzenia weekendu od piątku do niedzieli (3-5 października 2008 r.), szczególnie w Wielkiej Brytanii, nie pozostawiały

35 Por. A. Jordan, C. Bryan-Low, A. MacDonald, M. Esterl, Iceland Created Vast Bubble, Leaving Wreckage Everywhere When it Popped, „The Wall Street Journal” 29.12.2009.

${ }^{36}$ Por. ibidem. Decyzję w tej kwestii, w formie porozumienia rządu z głównymi udziałowcami przy współpracy z Bankiem Centralnym Islandii i Komisją Nadzoru Finansowego, ogłoszono w poniedziałek 29 września 2008 r. Forma porozumienia była konieczna, bowiem ustawę dopuszczającą częściową lub całkowitą nacjonalizację banków Alpingi uchwalił dopiero w poniedziałek 6 października, możliwości takiej zaś nie przewidywały istniejące dotąd regulacje ustawowe. Por. http://eng.forsætisraduneyti.is/news-andarticles, 14.04.2011.

37 Por. Á. Jónsson, Why Iceland?, op.cit., s. 151-152. Kaupthing Edge prowadził ponad 330 tys. rachunków klientów z 11 państw, rachunki te w sumie opiewały na 5,2 mld euro. 
złudzeń co do powagi sytuacji ${ }^{38}$. Przemówienie premiera do narodu w poniedziałek 6 października miało już zupełnie inny charakter. Jego słowa, że Islandczycy stoją przed „realnym niebezpieczeństwem, że ich gospodarka w najgorszym wypadku może zostać wessana w globalne zawirowania, czego efektem może być narodowe bankructwo", zostały powtórzone przez większość światowych agencji i serwisów informacyjnych ${ }^{39}$.

W dniu 8 października miało miejsce kilka wydarzeń o kluczowym znaczeniu dla rozwoju sytuacji. Tego dnia islandzka Komisja Nadzoru Finansowego (FME) wprowadziła do Glitnir Banku zarząd komisaryczny, co w praktyce oznaczało jego pełne przejęcie przez państwo. Do tego czasu udziały państwa wynosiły $75 \%$. Również 8 października 2008 r. państwo islandzkie przejęło pełną kontrolę nad Landsbanki, który utracił płynność i nie był w stanie obsługiwać swoich klientów, szczególnie związanych z londyńskim oddziałem IceSave ${ }^{40}$. Było to jednakże następstwem poczynań rządu brytyjskiego, które do dziś budzą liczne kontrowersje i oceny. Zdecydowana większość Islandczyków, od środowisk biznesu i banków do rybaków i zwykłych obywateli, ocenia postępowanie Brytyjczyków zdecydowanie negatywnie zarówno w kategoriach rynków finansowych, jak i w kategoriach moralnych. Minister Skarbu Rządu, JKM A. Darling, wydał rozporządzenie Landsbanki Freezing Order 2008, w którym zawarta była decyzja o zamrożeniu aktywów Landsbanki w Wielkiej Brytanii i dalszych krokach zmierzających do zabezpieczenia interesów ponad 300 tys. brytyjskich deponentów w IceSave. Rozporządzenie zostało wydane na podstawie ustawy Anti-Terrorism, Crime and Security Act uchwalonej przez Izbę Gmin w 2001 r. po atakach na World Trade Center, w której przewidziano możliwość zastosowania nadzwyczajnych działań przez rząd w sytuacji zagrożenia bezpieczeństwa Wielkiej Brytanii lub gdy podjęte zostały działania mogące narazić na szkodę (straty) jej gospodarkę, a nawet jeśli wystąpiło prawdopodobieństwo podjęcia takich działań. W ten sposób zamrożonych zostało ok. 4 mld funtów aktywów islandz-

38 Sami Islandczycy albo z zapartym tchem zajęli miejsca przed telewizorami i monitorami komputerów, albo prowadzili niezliczone rozmowy telefoniczne z rodzinami i przyjaciółmi, głównie zagranicą. Opustoszało centrum Reykjaviku, ustał ruch samochodowy, nawet na Bankastræti i Austurstræti, które są wizytówkami stolicy. Kolejne Hammery, Porsche czy Range Rovers'y nie podjeżdżały pod restauracje i kluby w centrum, z których i tak znaczna część była zamknięta. Wyczuć można było, czego sam doświadczyłem, atmosferę zbliżającej się katastrofy. Opustoszały dworce autobusowe Hlemmur i Lækjartorg, zwykle pełne podróżnych, wszyscy oczekiwali nowych informacji o sytuacji na rynkach finansowych i decyzjach w Londynie i w siedzibie rządu islandzkiego. Kreppa - to słowo było najczęściej używane przez miejscowych w ten późnojesienny weekend.

39 Treść przemówienia premiera G. Haardego do narodu opublikowana przez Kancelarię Premiera Islandii 6 października 2008 r. Por. także: L. Baj, E. Olszewska, Islandia na progu piekła, „Gazeta Wyborcza” 08.10.2008; J. Kamiński, Islandia bliska bankructwa, „Dziennik Gazeta Prawna” 08.10.2008.

40 Por. D. Teather, Iceland Government Seizes Control of Landsbanki, „The Guardian” 07.10.2008. 
kich w Wielkiej Brytanii ${ }^{41}$, ale jednocześnie legalnie działające w Wielkiej Brytanii banki i inne firmy islandzkie postawiono $\mathrm{w}$ jednym szeregu $\mathrm{z}$ organizacjami terrorystycznymi oraz zorganizowaną przestępczością! Wielkość aktywów islandzkich w Zjednoczonym Królestwie była wystarczająca na pokrycie zobowiązań, pod warunkiem nie wzbudzania paniki na rynku i spokojnego poszukiwania kompromisowych rozwiązań (np. udzielenie czasowych gwarancji lub linii kredytowej przez Bank of England, tak jak uczynił to dokładnie 8 października Sveriges Riksbank, uruchamiając liczącą ponad $520 \mathrm{mln}$ euro linię kredytową dla Kaupthing Sverige $\mathrm{AB}$, aby umożliwić realizację wypłat dla deponentów i innych wierzycieli ${ }^{42}$ ). Widać jednak, że o ile skandynawskie banki próbowały pomóc Islandczykom, o tyle bank centralny Anglii i instytucja nadzoru uznały sytuację za dobry pretekst, aby pozbyć się części konkurencji ze swojego terytorium.

Losy trzeciego, a zarazem największego w tym czasie banku islandzkiego również rozstrzygnęły się w Wielkiej Brytanii, co wskazuje, że działania w dniu 8 października miały skoordynowany charakter. Tego dnia brytyjski Financial Supervisory Authority (FSA) zdecydował o przejęciu aktywów Kaupthing Singer \& Friedlander na terytorium Wielkiej Brytanii i przekazaniu ich do ING Banku oraz wprowadzeniu do tego pierwszego zarządu komisarycznego ${ }^{43}$. Spowodowało to kolejne problemy, w rezultacie których bank macierzysty nie mógł się uratować i następnego dnia, 9 października, rząd islandzki podjął decyzję o przejęciu Kaupthing Bank, co było jednoznaczne z jego nacjonalizacją. Na Wyspach Brytyjskich, po początkowych restrykcjach wobec banków islandzkich, zarówno Ministerstwo Skarbu, jak i FSA złagodziły swoje stanowisko i działania, zezwalając na ograniczone funkcjonowanie Landsbanki, a Bank of England uruchomił pożyczkę w wysokości $100 \mathrm{mln}$ funtów na umożliwienie spłaty brytyjskich depozytariuszy ${ }^{44}$.

Porozumienie zawarte przez przedstawicieli rządów Holandii i Islandii w dniu 11 października poprawiało sytuację ok. 125 tys. obywateli Holandii, którzy mieli depozyty w IceSave. Przewidywało ono, iż islandzki fundusz gwarancyjny, Tryggingarsjóður Innstæðueigenda og Fjárfesta (TIF), pokryje oszczędności klientów do wysokości 20877 euro, zgodnie z Dyrektywą 94/19/EEC Parlamentu Europejskiego, wykorzystując do tego celu pożyczkę rządu Holandii. Po stronie brytyjskiej rozliczenia gwarancyjne były bardziej złożone ze względu na już podjęte przez władze działania. Ze strony Financial Services Compensation Scheme (FSCS) wypłaconych

\footnotetext{
${ }^{41}$ Por. UK Freezes $£ 4 b n$ of Icelandic Assets, „Daily Telegraph” 12.10.2008.

42 Por. Kaupthing Edg is Being Wound Up, Sveriges Riksbank, 08.10.2008.

43 Por. Kaupthing Singer \& Friedlander Limited Transfer of Certain Rights and Liabilities Order 2008, No. 2674, Office of Public Sector Information, London, 08.10.2008. Transfer objął ponad 160 tys. klientów banku z depozytami wartości ponad 2,5 mld funtów.

${ }^{44}$ Por. S. Jones, Landsbanki Gets £100m Loan to Pay UK Depositors, „The Guardian” 14.10.2008.
} 
zostało ok. 3 mld funtów pochodzących z „przetransferowanych depozytów z Heritable Banku i Kaupthing Singer \& Friedlander do ING Direct. Ministerstwo Skarbu zapłaciło dodatkowe $600 \mathrm{mln}$ GBP ponad limit określony przez FSCS oraz analogiczne $800 \mathrm{mln}$ GBP w stosunku do rachunków IceSave. Wszystkie te środki wypłacane klientom islandzkich banków poddane zostały konwersji w zbiorczą pożyczkę dla Islandii ostatecznie uzgodnioną w listopadzie $2008 \mathrm{r}{ }^{35}$ Rozstrzygnięcia te, jak miało się wkrótce okazać, nie zakończyły tzw. sprawy IceSave, ale tak naprawdę dopiero ją rozpoczęły.

\subsection{Przedterminowe wybory parlamentarne w 2009 r.}

Bezpośrednim politycznym skutkiem powyższych wydarzeń było wystąpienie z koalicji rządowej ugrupowania socjaldemokratycznego - Sojuszu, który nie zamierzał brać politycznej odpowiedzialności za upadek systemu bankowego, oraz jego gospodarcze i społeczne skutki. Wobec utraty przez Partię Niepodległości większości w Alpingi, premier G.H. Haarde 26 stycznia 2009 r. został zmuszony do złożenia na ręce prezydenta Republiki, Ólafura R. Grímssona, wniosku o dymisję rządu. W dniu 1 lutego 2009 r. na stanowisko premiera rządu desygnowana została przez prezydenta Ó.R. Grímssona pani Jóhnna Sigurðardottir. Nowy rząd, liczący łącznie z panią premier 10 osób, składał się z przedstawicieli Sojuszu i Lewicy - Ruchu Zielonych i był rządem mniejszościowym. Popierało go 27 deputowanych Alpingi (18 z Sojuszu i 9 z Lewicy - Ruchu Zielonych) na ogólną liczbę 63 deputowanych. Jednak jego mandat dodatkowo poparł prezydent (który wywodzi się z opcji socjaldemokratycznej), a także społeczeństwo dotknięte skutkami kryzysu, negatywnie oceniające dotychczasowego premiera i czynnie występujące przeciwko niemu i wspierającej go Partii Niepodległości. Od powołania rządu politycy byli jednak świadomi, że jest to rząd przejściowy, którego zadaniem jest administrowanie państwem i przygotowanie przedterminowych wyborów do Alpingi.

Panika i strach z przełomu września i października 2008 r., które ogarnęły przede wszystkim mieszkańców Reykjaviku i okolic, ustąpiły miejsca gniewowi wobec bankierów i polityków, którzy doprowadzili do „katastrofy”. Zaczęto publicznie mówić o patologiczno-korupcyjnych i oligarchicznych powiązaniach między politykami i finansistami związanymi przede wszystkim z rządzącą „od zawsze” Partią Niepodległości. Skala niefrasobliwości, życia na kredyt i na pokaz, niekompetencji oraz często bezmyślności osób podejmujących najważniejsze decyzje w sektorze bankowym

\footnotetext{
${ }^{45}$ Ibidem, s. 256.
} 
i w polityce zaszokowała zagranicznych ekspertów ${ }^{46}$. Bankierzy i politycy z kolei, usprawiedliwiając swoją chciwość, brak kompetencji i arogancję, winili drapieżny kapitalizm za swój los i przede wszystkim Stany Zjednoczone i Wielką Brytanię̨ ${ }^{47}$. Ta druga „wyrosła” wręcz w oczach przeciętnego Islandczyka na wroga zewnętrznego nr 1.

Powstały rząd, cieszący się poparciem mniejszości deputowanych w parlamencie, nie mógł w pełni się zaangażować w działania zmierzające do rozwiązywania i naprawy problemów finansowych, gospodarczych i społecznych, jakie spowodowała kryzysowa katastrofa. Można było z łatwością przewidzieć, iż deputowani Partii Niepodległości, a także posłowie Partii Postępu mający 32 mandaty z ogólnej liczby 63, a więc większość, będą utrudniać funkcjonowanie nowemu rządowi i przeciągać przede wszystkim debaty dotyczące odpowiedzialności za powstałą sytuację. Tymczasem wskaźniki gospodarcze na początku 2009 r. stawały się coraz bardziej alarmujące: spadał kurs korony islandzkiej, rosła inflacja (w skali 12 miesięcy wraz z I kw. 2009 r. stopa inflacji wynosiła 17,6\%) i bezrobocie, zatrzymany został wzrost gospodarczy. Islandia utraciła całkowicie wiarygodność na rynkach finansowych i wśród inwestorów, rosła frustracja i niezadowolenie społeczeństwa. Zwlekanie z radykalnymi decyzjami groziło pogłębieniem się tych negatywnych zjawisk wewnętrznych i izolacją międzynarodową państwa ${ }^{48}$.

Zgodnie z art. 24 Konstytucji Islandii prezydent może rozwiązać Alpingi i zarządzić nowe wybory, czyni to jednak zawsze na podstawie wniosku rządowego w sprawie oraz po konsultacji z premierem i szefami ugrupowań parlamentarnych. Wybory przedterminowe przeprowadzane są nie później niż w okresie 45 dni od momentu ogłoszenia rozwiązania, a o ich dokładnym terminie decyduje prezydent. Nowy parlament powinien się zebrać nie później niż w ciągu 10 tygodni od rozwiązania poprzedniego ${ }^{49}$. W odniesieniu do systemu wyborczego parlamentu konstytucja wskazuje expressis verbis tylko dwie zasady: tajności i proporcjonalności (art. 31), natomiast na podstawie art. 5 konstytucji domniemuje się o zasadach: powszechności i bezpośredniości. Szczegółowy tryb organizacji, przebiegu, obliczania głosów

${ }^{46}$ M.in. Kaarlo Jännäri, który przygotowywał Raport o regulacjach prawnych i nadzorze bankowym w Islandii, przedstawiony i dyskutowany na posiedzeniu rządu 30 marca 2009 r., Mark J. Flannery - ekspert Specjalnej Komisji Śledczej Alpingi wyjaśniającej przyczyny i okoliczności upadku islandzkiego sektora bankowego. Por. M.J. Flannery, Iceland's Failed Banks: A Post-Mortem, Special Investigation Commission, Reykjavik, 09.11.2009.

47 Por. R. Boyes, Meltdown Iceland.., op.cit., s. 186-196.

48 Opublikowane w $2010 \mathrm{r}$. dane dotyczące stanu gospodarki za $2009 \mathrm{r}$. w pełni potwierdziły te obawy, bowiem inflacja liczona rok do roku wyniosła $21,9 \%$, PKB zmniejszył się o $6,9 \%$, znacznie wzrosło zadłużenie gospodarstw domowych - do 14 mld USD, przy PKB o wartości 11,9 mld USD, itd.

49 Por. Konstytucja Republiki Islandii, tłumaczenie J. Osiński, op.cit., s. 41-42. 
i rozdziału mandatów w wyborach reguluje Ustawa o wyborach do Alpingi z 16 maja 2000 r. z późniejszymi zmianami ${ }^{50}$.

Przedterminowe wybory do parlamentu odbyły się ostatecznie 25 kwietnia $2009 \mathrm{r}$. po dość burzliwej, jak na warunki islandzkie, kampanii wyborczej ${ }^{51}$. Ich oficjalne rezultaty zawiera tabela 1 .

Tabela 1. Wyniki wyborów do Alpingi w latach 2007 i 2009

\begin{tabular}{|l|c|c|c|c|}
\hline \multicolumn{1}{|c|}{ Partie polityczne } & $\begin{array}{c}\text { \% głosów } \\
\text { w 2007 r. }\end{array}$ & $\begin{array}{c}\text { Liczba mandatów } \\
\text { w 2007 r. }\end{array}$ & $\begin{array}{c}\text { \% głosów } \\
\text { w 2009 r. }\end{array}$ & $\begin{array}{c}\text { Liczba mandatów } \\
\text { w 2009 r. }\end{array}$ \\
\hline $\begin{array}{l}\text { Partia Postępu } \\
\text { Framsóknarflokkur }\end{array}$ & 11,7 & 7 & 14,8 & 9 \\
\hline $\begin{array}{l}\text { Partia Niepodległości } \\
\text { Sjálfstæðisflokkur }\end{array}$ & 36,6 & 25 & 23,7 & 16 \\
\hline $\begin{array}{l}\text { Partia Liberalna } \\
\text { Frjálslyndi flokkurinn }\end{array}$ & 7,3 & 4 & 2,2 & 4 \\
\hline $\begin{array}{l}\text { Ruch Obywatelski } \\
\text { Borgarahreyfingin }\end{array}$ & - & - & 7,2 & 0 \\
\hline $\begin{array}{l}\text { Ruch Demokratyczny } \\
\text { Lýðræðishreyfingin }\end{array}$ & 26,8 & 18 & 29,8 & 20 \\
\hline $\begin{array}{l}\text { Sojusz } \\
\text { Samfylkingin }\end{array}$ & 14,3 & 9 & 21,7 & 14 \\
\hline $\begin{array}{l}\text { Lewica - Ruch Zielonych } \\
\text { Vinstrihreyfingin - grænt frambod }\end{array}$ & - & - & & 0 \\
\hline
\end{tabular}

Źródło: Statistics Iceland 2009, http:www.statice.is, 14.04.2011.

Wybory zakończyły się sukcesem partii dotychczas wspierających rząd i panią premier J. Sigurðardóttir, a więc Sojuszu skupiającego trwałych zwolenników opcji socjaldemokratycznej (wzrost z 18 do 20 mandatów w parlamencie i miano największego ugrupowania) i Lewicy - Ruchu Zielonych, stosunkowo nowego ugrupowania proekologicznego o rozbudowanym programie społecznym, którego sukces, w stosunku do poprzednich wyborów w 2007 r., był najznaczniejszy - powiększenie stanu posiadania z 9 do 14 mandatów. Łącznie obie partie, które postanowiły po wyborach kontynuować współpracę w ramach koalicji rządowej, mają 34 mandaty w 63-osobowym Alpingi. Było to pierwsze w historii niepodległej Islandii zwycięstwo w wyborach do parlamentu ugrupowań centrolewicowych.

${ }^{50}$ Lög um kosningar til Alpingis nr 24, 16 mai 2000, http://www.kosning.is/log_reglugerdir/althingi/, 14.04.2011.

${ }^{51}$ Szczegółowa analiza programów partii i przebiegu kampanii wyborczej wykracza poza ramy niniejszego opracowania. Jest zrozumiałe, że zasadniczą osią sporów politycznych były kwestie uświadomienia wyborcom, jak doszło do kryzysu i kto ponosi zań odpowiedzialność tak w odniesieniu do ugrupowań politycznych, jak i konkretnych osób wśród polityków i bankowców (D. Oddsson, G.H. Haarde, B. Gudmundsson, J.A. Johanesson). 
Dotkliwą porażkę w wyborach poniosła Partia Niepodległości, którą powszechnie obwiniano o brak nadzoru nad sektorem bankowym oraz zbyt bliskie związki koleżeńskie i biznesowe z instytucjami finansowymi. Obciążono ją również winą za sprzyjanie i umożliwienie ekspansji różnych firm powiązanych personalnie i kapitałowo z oligarchicznymi lub, jak akcentują to inni, mafijnymi rodzinami (klanami), które podporządkowały sobie niemal całą gospodarkę i przestrzeń publiczną. O tym, iż były to kwestie głęboko poruszające Islandczyków, świadczy bardzo wysoka frekwencja wyborcza. Z 227896 obywateli uprawnionych do głosowania w przedterminowych wyborach wzięły udział 193934 osoby, czyli 85,1\%.

Zasadniczym problemem do rozwiązania dla nowego rządu, rzutującym na międzynarodowe postrzeganie Islandii, pozostawała kwestia depozytów obywateli Wielkiej Brytanii i Holandii w IceSave, banku internetowym powiązanym z Landsbanki. O genezie problemu wspomniałem wcześniej. Po wyborach przyszedł dla rządu czas na zawarcie porozumienia z Wielką Brytanią i Holandią w tej kwestii.

Wcześniej jednak doszło do spektakularnej reorientacji polityki zagranicznej Islandii, zapowiadanej zresztą przez J. Sigurðardóttir po objęciu stanowiska premiera w lutym 2009 r. oraz podczas kampanii przed przedterminowymi wyborami do Alpingi w kwietniu $2009 \mathrm{r}$. Badania opinii publicznej przed wyborami i po wyborach, przeprowadzane przez Instytut Gallusa w kwietniu i maju 2009 r., wskazywały przewagę zwolenników przystąpienia do UE. Przykładowo w maju 2009 r. 61,2\% badanych popierało ewentualne starania o członkostwo w UE Islandii, 29,6\% zaś było przeciwko, pozostałe 9,2\% nie miało zdania w sprawie. Wśród ugrupowań politycznych także nie było jedności w kwestii członkostwa. Dla partii wspierających rząd sprzeciw Partii Niepodległości czy Partii Postępu był czymś naturalnym, bowiem w przeszłości obie te partie zdecydowanie przeciwstawiały się dążeniom integracyjnym. Głównymi argumentami były: utrata suwerenności państwa, którą Islandia odzyskała po latach w 1944 r., kwestia połowów ryb i owoców morza w islandzkiej 200-milowej strefie ekonomicznej, wspólna polityka rolna oraz kwestia utraty swojej tradycji i tożsamości przez niewielki naród. Dla socjaldemokratycznego Sojuszu największym problemem był jego eurosceptyczny partner koalicyjny Lewica - Ruch Zielonych, który programowo odrzucał wstąpienie do UE. Jego lider, Steingrimur Stigfusson, a zarazem minister finansów w obu rządach z panią premier J. Sigurðardóttir, na pytania, czy przystąpienie do UE ma związek z kryzysem bankowym i gospodarczym i czy jest konieczne, odpowiedział, że „można stwierdzić, iż Islandczycy chcieliby euro, lecz nie chcą członkostwa w UE. Jednak takie rozwiązanie nie jest możliwe”.

Rząd w dniu 25 maja 2009 r. przedłożył formalnie w Alpingi uchwałę w sprawie rozpoczęcia procesu akcesji do UE, a więc $\mathrm{w}$ miesiąc po przedterminowych wyborach parlamentarnych. Jej założenia były optymistyczne i przewidywały, że ze względu 
na to, iż Islandia jest państwem należącym do Europejskiego Obszaru Gospodarczego i do strefy Schengen, rokowania w sprawie członkostwa rozpoczną się w $2010 \mathrm{r}$. i powinny zakończyć się po 12 miesiącach, a akcesja powinna nastąpić 1 lipca $2011 \mathrm{r}$. lub 1 stycznia 2012 r. Przewidywano możliwość wstąpienia wspólnie z Chorwacją, jako 29 członek UE. Ostatecznie w sprawie akcesji rząd zapowiadał w planie przeprowadzenie ogólnonarodowego referendum, którego tylko pozytywny wynik byłby rozstrzygający w sprawie. Wielu obserwatorów było jednak bardziej ostrożnych w kreśleniu perspektywy przystąpienia - akcentowało przede wszystkim fakt katastrofalnego stanu finansów i gospodarki państwa, ogromnego zadłużenia zewnętrznego i nierozwiązanych kwestii dotyczących depozytów w IceSave i Edge. Sprawę wejścia do strefy euro uważano za abstrakcję w sytuacji finansowej państwa i pożyczek uruchomionych przez państwa skandynawskie i MFW oraz możliwości wypełnienia kryteriów przystąpienia. Dziś wiemy z całą pewnością, że rację mieli realiści, a sprawa członkostwa oddala się coraz bardziej, choć Islandia liczy na przyspieszenie sprawy w trakcie polskiej prezydencji od 1 lipca $2011 \mathrm{r}$.

Po wcześniejszych debatach w komisjach, plenarna dyskusja na temat uchwały $\mathrm{w}$ sprawie aplikacji o członkostwo Islandii w UE rozpoczęła się w parlamencie 10 lipca 2009 r. Po burzliwych obradach, którym towarzyszyły manifestacje zarówno zwolenników, jak i przeciwników przystąpienia do UE, Alpingi 16 lipca 2009 r. przyjął wspomnianą uchwałę zaproponowaną przez rząd. Za jej przyjęciem opowiedziało się 33 deputowanych, 28 było przeciw, 2 zaś wstrzymało się od głosu. Wśród głosów sprzeciwu było 5 oddanych przez członków rządzącej koalicyjnej partii Lewica - Ruch Zielonych. Po głosowaniu premier J. Sigurðardóttir w wypowiedzi dla Agencji Reuters stwierdziła, że „było to prawdopodobnie głosowanie o najbardziej historycznym znaczeniu od czasu ustanowienia republiki. Nie mam wątpliwości, że decyzja ta będzie korzystna dla mieszkańców Islandii”. Kopię decyzji parlamentu w dniu 17 lipca ambasador Islandii w Sztokholmie, Gudmundur Arni Stefansson, przekazał na ręce prezydencji szwedzkiej w Ministerstwie Spraw Zagranicznych, a ambasador pełnomocny Islandii przy UE, Stefan Haukur Johannsson, również 17 lipca 2009 r., przedłożył wniosek swego państwa w Komisji Europejskiej w Brukseli. Oficjalny dokument prezydencji szwedzkiej przekazany został osobiście przez ministra spraw zagranicznych Islandii, Ossura Skarphedinssona, w dniu 23 lipca 2009 r. na ręce ministra spraw zagranicznych Szwecji, Carla Bildta ${ }^{52}$.

52 Tego samego dnia, 23 lipca 2009 r., uchwałę popierającą islandzkie dążenie do członkostwa w UE przyjął Sejmas - parlament Litwy. Był to „swoisty rewanż” za to, iż Islandia była pierwszym państwem na świecie, które uznało odrodzoną Republikę Litwy i zaproponowało nawiązanie stosunków dyplomatycznych 26 sierpnia $1991 \mathrm{r}$. Oficjalnie pierwsze cztery rozdziały negocjacji zostały otwarte 27 czerwca 2011 r., czyli w przededniu rozpoczynającej się polskiej prezydencji w Radzie Unii Europejskiej. 


\subsection{Ogólnonarodowe referenda w tzw. sprawie IceSave}

Na fali paniki, jaka ogarnęła Brytyjczyków i Holendrów posiadających depozyty w IceSave, instytucje nadzorujące rynki finansowe w tych państwach podjęły decyzje o wypłatach swoim obywatelom $z$ bankowych funduszy gwarancyjnych depozytów utraconych po zawieszeniu wypłat, a w zasadzie po upadku Landsbanki. Nacjonalizacja banku w dniu 8 października 2008 r. niewiele zmieniła sytuację, bowiem Bank Centralny Islandii nie był w stanie zagwarantować środków finansowych na pokrycie masowego wycofywania wkładów z IceSave. „Grzechem pierworodnym” w tej sytuacji był fakt, że brytyjski Financial Services Compensation Scheme (FSCS) wraz z Ministerstwem Skarbu ustaliły, iż wypłaty dla obywateli brytyjskich z funduszu gwarancyjnego będą wypłacane w pełnej wysokości depozytów, jednakże nie konsultowały tej decyzji z władzami islandzkimi, które stały od początku na stanowisku, że są zobowiązane prawnie (wspomniana Dyrektywa 94/19/EEC) do wypłaty gwarancji minimalnych do wysokości 20887 euro na jeden depozyt. Z kolei władze holenderskie początkowo przyjmowały za podstawę wypłatę gwarancji minimalnych, a następnie pod naciskiem właścicieli depozytów podjęły decyzję o podniesieniu wypłat $\mathrm{z}$ funduszu gwarancyjnego do 100 tys. euro. Społeczeństwo islandzkie i część polityków obie te decyzje, brytyjską i holenderską, potraktowało jako niepowodujące skutków finansowych dla Islandii. Były to wewnętrzne decyzje wspomnianych państw $\mathrm{w}$ relacjach $\mathrm{z}$ ich obywatelami, stroną których nie były oficjalne organy islandzkiego państwa, bowiem one nie zostały nawet wcześniej o nich poinformowane.

Jednakże w celu uchronienia wizerunku Islandii i dobrych relacji międzynarodowych, a także w obliczu pierwszej transzy pomocy finansowej z MFW, zobowiązanie rządu Islandii do uregulowania kwestii długów pozostałych po IceSave wyrażone zostało $\mathrm{w}$ porozumieniu międzyrządowym zawartym przez Islandię, Wielką Brytanię i Holandię pod auspicjami UE w Brukseli 14 listopada 2008 r. Dotyczyło ono trzech kwestii: (1) uznania przez strony, że sytuacja prawna dotycząca funduszu gwarancyjnego depozytów powinna być rozstrzygana w oparciu o Dyrektywę 94/19/EEC Parlamentu Europejskiego, mającą zastosowanie wobec Islandii jako członka Europejskiego Obszaru Gospodarczego, (2) uznanie, iż ustalenia końcowe dotyczące finansowego wsparcia Islandii, włączając w to Międzynarodowy Fundusz Walutowy, będą brały pod uwagę szczególne okoliczności, w jakich znalazła się Islandia w rezultacie kryzysu, i będą uwzględniać jej dążenie do odbudowy systemu finansowego i gospodarki, (3) potrzeby dalszego uczestnictwa instytucji UE i EOG w procesie negocjacji, które będą prowadzone w konsultacji z nimi. Na podstawie tych tzw. wytycznych brukselskich Alpingi przyjęło 5 grudnia 2008 r. uchwałę 
zobowiązującą rząd islandzki do negocjacji i zawarcia porozumienia w kwestii spłaty zobowiązań powstałych po upadku IceSave.

Po zakończeniu negocjacji 5 czerwca 2009 r. podpisane zostały dwa porozumienia regulujące omawiany problem. Pierwsze: Porozumienie w sprawie pożyczki zawarte pomiędzy Islandzkim Funduszem Gwarancyjnym Depozytariuszy i Inwestorów (Tryggingarsjóður Innstæðueigenda og Fjárfesta - TIF) i Islandią a Ministerstwem Skarbu JKM, drugie: Porozumienie w sprawie pożyczki zawarte pomiędzy Islandzkim Funduszem Gwarancyjnym Depozytariuszy i Inwestorów (Tryggingarsjóður Innstæðueigenda og Fjárfesta - TIF) i Islandią a Holandią. Dodatkowo w tym samym dniu 5 czerwca 2009 r. podpisane zostało Porozumienie w sprawie rozliczenia pomiędzy Financial Services Compensation Scheme (FSCS) a Tryggingarsjóður Innstæðueigenda og Fjárfesta (TIF) dotyczące współdziałania obu tych, dodajmy prywatnych, instytucji zajmujących się wypłatami dla depozytariuszy ${ }^{53}$.

Zasadniczym dążeniem stron brytyjskiej i holenderskiej było zobowiązanie się państwa islandzkiego do uczestniczenia w spłacie długów powstałych w rezultacie upadku IceSave, ale także nacjonalizacji Landsbanki. Zarówno bank, jak i IceSave były wcześniej instytucjami prywatnymi, wobec czego nie mogło być mowy o udziale państwa w spłacaniu ich długów, chyba że wolę taką wyraziłby islandzki parlament. Jak wspomniałem, prywatny charakter miał także Islandzki Fundusz Gwarancyjny Depozytariuszy i Inwestorów, w związku z czym jego zobowiązania wobec podobnych instytucji w Wielkiej Brytanii czy Holandii, jak również władz państwowych nie miały mocy wiążącej dla rządu i parlamentu islandzkiego.

Osiągnięte porozumienia oceniano nie tylko w Islandii jako skrajnie niekorzystne dla tego państwa. Podkreślano, że szczególnie Wielka Brytania zachowuje się nie fair wobec pogrążonego w kryzysie małego państwa, łamiąc niekiedy dobre zwyczaje przyjęte w stosunkach międzynarodowych w relacjach pomiędzy państwami. Dąży do narzucenia Islandii bardzo trudnych do spełnienia warunków, które dotykają głęboko poczucia godności narodu i mogą spowodować, że kraj na wiele lat pogrąży się w stagnacji i drastycznie obniży się jego poziom rozwoju gospodarczego i społecznego. Znacząco różniło się to od postawy państw nordyckich, które w zbiorczej pożyczce przedstawionej do dyspozycji rządu islandzkiego w lipcu 2009 r. przyjęły najniższe z możliwych oprocentowanie w wysokości 2,75\%, Brytyjczycy zaś we wspomnianym porozumieniu wymogli akceptację $5,55 \%$ stawki do $2024 \mathrm{r}$. W powszechnej

\footnotetext{
${ }^{53}$ Por. wersje angielskie dokumentów: Loan Agreement dated 5 June 2009 between The Depositors' and Investors' Guarantee Fund of Iceland and Iceland and The Commissioners of Her Majesty's Treasury, Loan Agreement dated 5 June 2009 between The Depositors' and Investors' Guarantee Fund of Iceland and Iceland and The State of The Netherlands oraz Settlement Agreement dated 5 June 2009 between Financial Services Compensation Scheme and The Depositors' and Investors' Guarantee Fund of Iceland, http://www.althingi.is, 14.04.2011.
} 
opinii Islandczyków, pracujący rybacy, farmerzy, nauczyciele, lekarze i pielęgniarki, wszyscy płacący podatki, nie mogą wziąć na swoje barki ciężaru, który spowodowali nieodpowiedzialni, chciwi bankierzy. Stwierdzenie: „To nie nasz dług” - powtarzane było wielokrotnie.

Wspomniane porozumienia mogły wejść w życie dopiero po przyjęciu stosownej ustawy w Alpingi, której projekt przygotowywało Ministerstwo Finansów. Zgodnie $\mathrm{z}$ art. 40 Konstytucji Islandii zaciągnięcie jakiejkolwiek pożyczki wiążącej państwo może zostać dokonane tylko na mocy ustawy uchwalonej przez parlament. Stąd 30 czerwca 2009 r. stosowny projekt został wniesiony pod obrady, jako projekt ustawy nr 96/2009, i wywołał burzliwe debaty. Porozumienia przewidywały upoważnienie ministra finansów w imieniu Skarbu Państwa do przyznania gwarancji państwa dla pożyczek udzielonych przez władze brytyjskie i holenderskie Islandzkiemu Funduszowi Gwarancyjnemu Depozytariuszy i Inwestorów przeznaczonych na płatności zwrotów depozytów w Landsbanki ${ }^{54}$. W praktyce wypłaty za depozyty dotyczyły ok. 300 tys. Brytyjczyków i 125 tys. Holendrów.

Pożyczka zbiorcza udzielona przez Wielką Brytanię wyniosła 2,35 mld funtów, przez Holandię zaś 1,3 mld euro, co w sumie dawało ok. 3,8 mld euro (ok. 5,7 mld USD). Islandia miała rozpocząć spłatę pożyczek od 5 czerwca 2016r. i zakończyć po wpłaceniu 32 równych rat do 5 czerwca 2024 r. Ostateczna realizacja wszystkich płatności powinna nastąpić przed 5 czerwca 2024 r., także tych powstałych $\mathrm{w}$ trakcie realizacji porozumienia. Jednakże strona islandzka mogła jednostronnie przedłużyć okres korzystania z pożyczek do dnia 5 czerwca 2030 r. Oprocentowanie obu pożyczek określono na 5,55\%. Wielkość rocznej raty miała być określana na podstawie wielkości skumulowanego PKB z roku poprzedniego i uwzględnieniu ekwiwalentu wzrostu gospodarczego (po 2016r. - 2\%), wyrażonych w islandzkich koronach konwertowanych na euro na podstawie średniego kursu wymiany publikowanego przez Bank Centralny Islandii. Jednakże średnio, przy założeniu, że PKB Islandii wynosiłby ok. 11495000000 euro (jak w 2008 r.), z uwzględnieniem ekwiwalentu wzrostu od 2016 r. o 1\%, spłata wynosiłaby ok. $540 \mathrm{mln}$ euro w skali roku, co stanowiłoby średnio ok. 5\% wartości rocznego PKB, czyli ok. 135 USD miesięcznie przez 8 lat w przeliczeniu na obywatela Islandii ${ }^{55}$.

54 Por. wersję angielską projektu: Act No 96/2009 regarding authorization for the Minister of Finance, on behalf of the State Treasury, to issue a state guarantee of the lons granted by the governments of the UK and the Netherlands to the Depositors' and Investors' Guarantee Fund of Iceland to enable it to cover payments to the depositors of Landsbanki Ísland hf., http://www.althingi.is, 14.04.2011.

55 Wyliczenia te są przybliżone, bowiem trudny jest do oszacowania w warunkach pokryzysowych realny wzrost PKB Islandii. Szczegółowa analiza uwarunkowań prawnych, międzynarodowych, budżetowych i ekonomicznych wprowadzenia po zmianach ustawy nr 19/2009 Alpingi została opublikowana 21 października 2009 r. Por. http://www.althingi.is, 14.04.2011. 
Ostatecznie parlament po dyskusjach w komisjach stałych i na podstawie rekomendacji Komisji Budżetu z 15 sierpnia 2009 r. $^{56} \mathrm{w}$ dniu 28 sierpnia 2009 r. przyjął ustawę nr 96/2009 zawierającą upoważnienie dla ministra finansów, jednak z wieloma warunkami wstępnymi i zasadniczymi uwagami do art. 1-4. Uchwalony, ale zmieniony projekt ustawy przedstawiono rządom Wielkiej Brytanii i Holandii do akceptacji. Ostatecznie w wyniku negocjacji ustalono, że zawarte porozumienia powinny zostać uzupełnione i zmienione poprzez nowe Porozumienia dotyczące zmian zawartych wcześniej Porozumień w sprawie pożyczki oraz Porozumienia $\mathrm{w}$ sprawie rozliczenia, zawartego pomiędzy instytucjami funduszy gwarancyjnych (brytyjskim FSCS i islandzkim TIF) obsługującymi wypłaty i rozliczenia. Wszystkie trzy Porozumienia dotyczące zmian zostały podpisane przez strony 19 października 2009 r. I tak, jak poprzednio, ich wejście w życie uzależnione było od uchwalenia stosownej ustawy przez parlament.

Prace w Alpingi rozpoczęły się od początku 138 sesji zwyczajnej parlamentu zwołanej zgodnie z art. 35 Konstytucji Islandii 1 października. Podpisanie 19 października 2009 r. poprawek do porozumień rząd traktował jako swój sukces i realizację uchwały parlamentu z 5 grudnia 2008 r. zobowiązującej ówczesny rząd do doprowadzenia do końca kwestii długów po upadku IceSave. Opozycja akcentowała niekorzystne, jej zdaniem, warunki porozumień z 5 czerwca i negowała sens negocjacji z Wielką Brytanią i Holandią, bowiem szczególnie ta pierwsza próbowała upokorzyć Islandię podejmowanymi jeszcze we wrześniu i październiku $2008 \mathrm{r}$. działaniami ${ }^{57}$.

Ostatecznie po niemal 2-miesięcznych debatach 30 grudnia 2009 r. parlament uchwalił ustawę nr 1/2010 zmieniającą ustawę nr 96/2009 z 28 sierpnia $2009 \mathrm{r}$. „dotyczącą upoważnienia dla ministra finansów w imieniu Skarbu Państwa do przyznania gwarancji państwa dla pożyczek udzielonych przez rządy Wielkiej Brytanii i Holandii Islandzkiemu Funduszowi Gwarancyjnemu Depozytariuszy i Inwestorów, przeznaczonych na pokrycie wypłat dla depozytariuszy Landsbanki Íslands hf”. Za zmienioną ustawą (nazywana w skrócie ustawą o IceSave) głosowało 33 deputowanych w większości z partii koalicji rządowej (Sojuszu i Lewicy - Ruchu Zielonych), przeciwko było 30 deputowanych Alpingi wywodzących się z Partii Niepodległości i Partii Postępu ${ }^{58}$. Wynik głosowania świadczy o determinacji koalicji rządzącej

\footnotetext{
56 Tekst rekomendacji Komisji Budżetu Alpingi z 15 sierpnia 2009 r. patrz: www.island.is, 14.04.2011.

${ }^{57}$ Podkreśla się, że w rezultacie upadku innego islandzkiego banku - Kaupthing - i powiązanego z nim banku internetowego Edge, który zdołał zgromadzić na rynku niemieckim depozyty o wysokości $400 \mathrm{mln}$ euro gwarantowane przez islandzki fundusz gwarancyjny, nie było ani przez moment wątpliwości, iż depozyty te zostaną utracone przez klientów. Depozyty te zostały spłacone w całości do pełnej wysokości. Postępowanie brytyjskie było wrogie i aroganckie wobec małego narodu i państwa. Por. Á. Jansson, Why Iceland?, op.cit., s. 197-199.

${ }^{58}$ Por. http://www.althingi.is, 14.04.2011.
} 
w działaniach zmierzających do zamknięcia „kwestii IceSave” (przynajmniej dla obserwatorów zewnętrznych) tak, aby nie narażać wizerunku państwa w relacji z UE i jej państwami członkowskimi. Jednakże wiele wypowiedzi na forach internetowych i portalach społecznościowych, jak również część badaczy, szczególnie prawników, wskazuje na wady zawartych porozumień i ich niekiedy sprzeczność $\mathrm{z}$ islandzkim prawem, a tym samym krytykuje przepisy zawarte w przyjętej ustawie ${ }^{59}$.

Zgodnie z Konstytucją Islandii (art. 26) projekt ustawy uchwalony przez Alpingi przedkładany jest prezydentowi do potwierdzenia (promulgacji), co powinien uczynić nie później niż w ciągu 2 tygodni od jego uchwalenia. Po potwierdzeniu projekt staje się obowiązującą ustawą. Prezydent może jednak odmówić potwierdzenia, co skutkuje poddaniem projektu ustawy ogólnonarodowemu referendum, które powinno odbyć się tak szybko, jak pozwalają na to okoliczności. Prawo uczestniczenia w referendum mają wszystkie osoby posiadające czynne prawo wyborcze w wyborach do parlamentu, a głosowanie odbywa się przy zachowaniu zasady tajności. Prezydent Ó.R. Grimsson, pod wpływem masowych protestów odbywających się, co jest rzadkością, także przed jego siedzibą w Bessastaðir, już na początku stycznia $2010 \mathrm{r}$. zapowiedział, że nie podpisze ustawy. Ostatecznym argumentem była petycja do prezydenta, aby nie zatwierdzał ustawy, podpisana przez ok. 60 tys. obywateli, czyli 1/4 uprawnionych do głosowania w referendum. Akcję zbierania podpisów pod petycją zorganizował Ruch w Obronie Islandii (InDefence of Iceland). Odmowa złożenia podpisu pod ustawą przez prezydenta miała miejsce po raz pierwszy (jak dotąd jedyny) 2 czerwca 2004 r. i wówczas spotkała się z nieprzychylnym przyjęciem. Zarzucano prezydentowi, że kieruje się własnymi socjaldemokratycznymi poglądami (czynili to politycy rządzących wówczas Partii Niepodległości i Partii Postępu, którzy przegłosowali ustawę w Alpingi), a - upolityczniając decyzję - nie dba o interes kraju ${ }^{60}$. Tym razem jednak społeczeństwo zdecydowanie domagało się weta prezydenta,

59 Przykładowo, Ragnar Hall w „Frettabladid” (http://newsfrettir.com/banks/landsbanki/1050-amistake-in-the-icesave-agreement, 14.04.2011) wskazywał, iż wiele z postanowień zawartych porozumień jest w sprzeczności z islandzką ustawą o bankructwie, bowiem każda skarga czy żądanie wypłaty depozytu w przypadku takich podmiotów, jak IceSave zgodnie z islandzkim prawem powinna być rozpatrywana odrębnie, niezależnie od istnienia ogólnych gwarancji depozytów. Również brytyjski FSCS podjął wiele jednostronnych decyzji, część bez wiedzy, a część za wiedzą TIF, jednakże nie na podstawie wcześniejszej umowy czy porozumienia z TIF. A więc to on ponosi konsekwencje takich decyzji, próbując je ex post przerzucić na TIF. Dodatkowo, obie organizacje maja prywatny charakter i ich ustalenia nie mają mocy wiążącej rząd. Por. także: http://www.vald.org/greinar/090728.html, 14.04.2011 oraz http://www.icenews.is/index. php/2009/07/29, 14.04.2011.

${ }^{60}$ Por. J. Osiński, Prezydent Republiki Islandii, op.cit., s. 339-340. Przypomnijmy, iż był to okres neoliberalnych deregulacji wszystkich możliwych sfer życia na Islandii, także własności i zarządzania mediami, czego dotyczyła wspomniana ustawa. Po latach ówczesna decyzja prezydenta okazała się właściwa i dalekowzroczna, choć nie mogła przeciwdziałać wspomnianym procesom skrajnej deregulacji i nieograniczonej prywatyzacji. 
mimo że ustawa przegłosowana została w parlamencie przez deputowanych bliskich mu ideowo i przygotowana przez takiż rząd. Ostatecznie 5 stycznia 2010 r. prezydent ogłosil, że nie zamierza podpisać ustawy, co jednoznacznie oznaczało konieczność przeprowadzenia ogólnonarodowego referendum w sprawie jej obowiązywania. Pozytywny wynik takiego referendum decyduje o uzyskaniu przez sporną ustawę mocy obowiązującej. W przeciwnym przypadku nie wchodzi ona w życie.

Termin referendum, zgodnie z prawem, wyznacza minister sprawiedliwości i praw człowieka w porozumieniu z Narodową Komisją Wyborczą. W omawianym przypadku został on wyznaczony na niedzielę 6 marca 2010 r. Podczas organizacji i w trakcie trwania referendum mają zastosowanie przepisy ustawy o wyborach do Alpingi z 16 maja 2000 r. z późniejszymi zmianami. Organizacja referendum przewiduje takie same sposoby oddawania głosów przez wszystkich uczestniczących, łącznie z głosowaniem listownym, głosowaniem przedterminowym i głosowaniem $\mathrm{w}$ islandzkich przedstawicielstwach dyplomatycznych w innych państwach i organizacjach międzynarodowych ${ }^{61}$.

Sondaże przed referendum wskazywały na ogromną przewagę przeciwników uchwalonej ustawy, którzy wcześniej zorganizowali wiele akcji zachęcających do sprzeciwu wobec rozwiązania zrzucającego na wszystkich obywateli spłatę zobowiązań powstałych w rezultacie niekompetentnych działań przedstawicieli establishmentu bankowego i polityków. Zaktywizowały się portale społecznościowe, nieformalne grupy przeciwników ustawy i organizacje pozarządowe, z których szczególną rolę odegrał wspomniany Ruch w Obronie Islandii (InDefence of Iceland), który powstał już w 2008 r. w odpowiedzi na nieprzyjazne kroki władz brytyjskich w stosunku do Landsbanki, o czym wspomniałem wcześniej. Wynik referendum był więc znany, choć nie można było przewidzieć skali sprzeciwu.

Po przeliczeniu głosów (ze względu na złe warunki pogodowe w północnowschodnim okręgu wyborczym głosy z wyspy Grimsey dotarły do komisji w Akureyri z opóźnieniem) i ogłoszeniu ostatecznych wyników referendum okazało się, że przewaga przeciwników wejścia w życie omawianej ustawy była przygniatająca. Spośród 144231 wyborców, którzy wzięli udział w referendum, aż 134397, czyli 93,2\%, opowiedziało się przeciwko ustawie. Tylko 2599 uczestników referendum, czyli 1,8\%, zaaprobowało jej wejście w życie. Czyste karty do głosowania oddało 6744 wyborców, czyli 4,7\%, a 491 oddanych kart, czyli 0,3\%, było nieważnych. Frekwencja

${ }^{61}$ Wspomniane rodzaje głosowania rozpoczynają się wcześniej, przed ustalonym terminem głosowania powszechnego. W przypadku pierwszego referendum w tzw. sprawie IceSave wyznaczonego przez minister sprawiedliwości i praw człowieka Ragnę Árnadóttir na 6 marca 2010 r., oddawanie głosów listowne, przedterminowe i w przedstawicielstwach dyplomatycznych rozpoczęło się już 28 stycznia $2010 \mathrm{r}$. Za granicą głosowanie odbywało się w 235 obwodach w 84 państwach. Por. http://www.kosning.is/english/, 14.04.2011. 
była niższa niż podczas przedterminowych wyborów do Alpingi (wówczas 85,1\%) i wyniosła $62,72 \%{ }^{62}$.

Wyniki referendum wywołały szeroką reakcję w Europie, a szczególnie w Wielkiej Brytanii i Holandii, co było w pełni zrozumiałe ze względu na ewentualne pozytywne skutki wejścia w życie ustawy dla obywateli tych państw. Przedstawiciele obu najbardziej zainteresowanych rządów wyrazili swoje rozczarowanie decyzją podjętą przez islandzkich obywateli w referendum. Strona islandzka zapewniała o swojej gotowości do ponownych negocjacji, które powinny doprowadzić do właściwego i satysfakcjonującego strony porozumienia.

Do nowych rokowań strona islandzka była znacznie lepiej przygotowana i nie dała się zepchnąć do defensywy, co zarzucano jej po rezultatach pierwszych negocjacji. Minęło nieco czasu od przełomu września i października 2008 r. i dokonano wstępnego oszacowania majątku pozostałego po „starym” Landsbanki. Z szacunków wynika, że można z niego pokryć ponad $90 \%$ zadłużenia IceSave wobec obywateli brytyjskich i holenderskich. $Z$ jego aktywów stale dokonywane są zwroty środków do tych dwóch państw, ale na ostateczne rozliczenie potrzeba jeszcze kilku lat. Wskazywano także, że w żadnym państwie fundusz gwarancyjny (nawet FDIC w Stanach Zjednoczonych) nie posiada środków wystarczających na pokrycie wszystkich depozytów w sytuacji totalnego krachu systemu bankowego, podobnego do tego w 2008 r. w Islandii. W interesie stabilności własnego systemu bankowego i finansowego rządy Wielkiej Brytanii i Holandii zdecydowały wówczas o wypłatach dla depozytariuszy IceSave bezpośrednio po tym, jak upadł Landsbanki. A następnie przesłały rachunek za ten transfer Islandczykom. Już pisałem o jednostronności decyzji władz obu państw w wielu kwestiach, lecz także one musiały uznać część argumentów.

Ostatecznym rezultatem negocjacji były porozumienia, które zawierały znacznie korzystniejsze warunki dla strony islandzkiej, m.in. okres zwrotu miał być wydłużony do 30 lat i obejmować lata 2016-2046, znacząco zmalało oprocentowanie długu, które w przypadku Wielkiej Brytanii miało wynosić $3,3 \%$, w przypadku zaś długu holenderskiego 3,0\%, inaczej sformułowano zobowiązania strony islandzkiej, co znalazło wyraz w nowym brzmieniu ustawy w omawianej sprawie. Przedmiotowa ustawa została uchwalona przez Alpingi 16 lutego 2011 r., a więc 11 miesięcy po pierwszym referendum. Za jej przyjęciem głosowało 44 z 63 członków parlamentu, a więc także część deputowanych opozycji. Ustawa nr 13/2011 dotyczyła upoważnienia ministra finansów do podpisania porozumienia w sprawie gwarancji (a) zwrotu z Funduszu Gwarancyjnego Depozytariuszy i Inwestorów Wielkiej Brytanii i Holandii kosztów

${ }^{62}$ Por. http://www.kosning.is/english/, 14.04.2011, a także: http://icelandreview.com/icelandreview/daily_ news, 06.03.2010. 
wynikłych z wypłat minimum gwarancyjnego depozytariuszom oddziałów (filii) Landsbanki Íslands hf. w Wielkiej Brytanii i Holandii oraz (b) płatności pozostałych związanych z tym zobowiązań bilansowych ${ }^{63}$.

Prezydent O.R. Grimsson i tym razem już 20 lutego 2011 r. odmówił potwierdzenia (promulgacji) ustawy, co poskutkowało przekazaniem jej pod ogólnonarodowe referendum, zgodnie z art. 26 Konstytucji Islandii. Referendum odbyło się 9 kwietnia 2011 r., a poprzedzająca kampania nie była tak burzliwa, jak przed pierwszym, ale bardziej rzeczowa, bowiem sami Islandczycy już się oswoili z postkryzysową sytuacją, od rozpoczęcia której upłynęło 2,5 roku. Pracę zakończyła Specjalna Komisja Alpingi, która przedstawiła obszerny raport w sprawie genezy, przyczyn, odpowiedzialności instytucji i osób oraz skutków katastrofy systemu bankowego. Specjalny prokurator prowadzący śledztwo w sprawie nadużyć i aspektów kryminalnych w funkcjonowaniu banków i instytucji powiązanych z tym sektorem przedstawił oskarżenia byłym członkom zarządów banków i urzędnikom Ministerstwa Finansów. W tej sprawie są pierwsi skazani prawomocnymi wyrokami sądowymi, jest zapowiedź postawienia byłego premiera G.H. Haardego przed Sądem Stanu (Trybunałem Stanu), zgodnie $\mathrm{z}$ art. 14 Konstytucji Islandii, itd. Wydarzenia te i inne (np. zatrzymanie działań związanych z akcesją Islandii do UE) skutkowały wyciszeniem emocji i zmniejszyły kontrowersje pomiędzy stronami.

Ostatecznie w referendum wzięło udział 177559 wyborców, co dało w skali państwa frekwencję 77,0\%. Za przyjęciem wspomnianej ustawy nr 13/2011 głosowały 69462 osoby, czyli 39,7\%, przeciw było 103207 wyborców, czyli 58,9\%, 2039 kart do głosowania było czystych, 406 głosów zaś uznano za nieważne. Mimo wyraźnie zmieniających się preferencji wyborców większość nie zamierza uczestniczyć w regulowaniu należności, które powstały poza ich kontrolą i w dużej części z winy władz holenderskich, a szczególnie brytyjskich.

\section{Zamiast zakończenia}

Politycznym skutkiem drugiego referendum był przedłożony w parlamencie wniosek o wotum nieufności dla rządu kierowanego przez panią J. Sigurðardóttir zgłoszony przez opozycję 13 kwietnia 2011 r., a więc cztery dni po przeprowadzonym referendum. Debata nad wnioskiem, jak podkreśla się w relacjach medialnych, miała

\footnotetext{
${ }^{63}$ Por. Statement from the Government of Iceland on the outcome of the referendum on the IceSave Agreements, http://www.icenews.is/index.php/2011/04/10/statement-from, 14.04.2011.
} 
retoryczny i teatralny charakter. $\mathrm{W}$ trakcie głosowania 30 deputowanych poparło wniosek, a 32 deputowanych było przeciw, jeden deputowany (Gudmundur Steingrimsson z Partii Postępu) wstrzymał się od głosu. Tym samym rząd przetrwał i może nadal realizować swój plan wychodzenia z kryzysu. Wspomniany wniosek o wotum nieufności połączony był $\mathrm{z}$ wnioskiem o rozwiązanie Alpingi i rozpisanie przedterminowych wyborów (zgłoszony również przez Partię Niepodległości). W głosowaniu wniosek poparło 22 deputowanych, 36 było przeciw, a 5 wstrzymało się od głosu ${ }^{64}$. Oba te zdarzenia pokazują, że toczy się i będzie się toczyć polityczna batalia wokół problemów wychodzenia z kryzysu i porządkowania relacji z zagranicą, szczególnie z państwami UE. Islandia może liczyć na wsparcie i współpracę z państwami skandynawskimi, które pomogły jej w najtrudniejszych momentach. Jednakże odbudowa pełnego zaufania do Islandii w relacjach międzynarodowych trwać będzie jeszcze wiele lat i dlatego oczekiwanie na pełne członkostwo w UE może się znacząco opóźnić, na tyle, iż być może w lepszej sytuacji gospodarczej w referendum akcesyjnym Islandczycy znowu powiedzą nei - nie.

\section{Political changes in Iceland in condtitions of an economic and banking crisis}

The author begins with a brief description of the essential political institutions of Iceland, as a republic with a parliamentary cabinet form of government and the special role of the president, arguing with the point of views that Iceland should be seen as a state with a semi-presidential form of government. Describing the political situation before the banking crisis, the author underlines the strong position of the Independence Party, which according to the results of the parliamentary elections (elections in 2007), plays a leading role in the "political life" of the state. The author pays attention to the process of oligarchisation in that party and the informal systems of social-network-based links and pathological links between the worlds of politics and business. Growing since the 90s, the dominance of a few family clans, together with the deregulation and privatization of the economy, led to nepotism and lack of accountability on the part of politicians and business representatives. An expansion of the three largest Icelandic banks Landsbanki, Kaupthing and Glitnir, without any significant criticism and state control, has led to a situation where at the end of 2008 their assets were 10 -fold greater than the GDP of Iceland. Loss of confidence in the interbank markets after the collapse of Lehman Brothers in the U.S., caused inhibition of liquidity and consequently the

${ }^{64}$ Por. http://www.icenews.is/index.php/2011/04/14/, 21.04.2011. 
collapse of these banks, eventually acquired by the state. The most spectacular was the collapse of Icesave - the Internet branch of Landsbanki operating in the UK and the Netherlands. The disintegration of the banking system led to a disintegration of the coalition government. Early elections in April 2009, won by the Social Democratic Alliance and the Left-Green Movement, led to the formation of a center-left government of Prime Minister, Ms J. Sigurðardóttir. The first major action was the government's reorientation of foreign policy and submitting an application for EU membership, and the subsequent arrangement of the debts after the collapse of these banks, reform of the central bank and banking supervisors, the establishment of a parliamentary committee to investigate the banking crisis and identify those responsible, the appointment of a special Prosecutor investigating violations of law during privatization of the banking sector and the actions taken on the eve of the crisis. The article contains the constitutional and legal analysis of the first and second so-called referendum. on Icesave, conducted after the President vetoed a further act concerning Iceland's agreements with its creditors - the United Kingdom and the Netherlands. As a result, residents of Iceland have not agreed to repay debts incurred without any fault on their part and through arrogance, incompetence and greed of the financial elite and the political managers controlling the banking system. This puts into question the country's future membership in the EU. The government, despite the opposition to the proposal made by a vote of no confidence, which fell, still take the difficult decisions associated with the revitalization of the banking system and economy of Iceland and improve its international image.

\section{Les changements politiques en Islande lors de la crise économique et bancaire}

Pour commencer, l'auteur se réfère aux principales institutions politiques en Islande, mettant l'accent sur le fait que cet État est une république parlementaire au sein de laquelle le président tient un rôle particulier. En décrivant la situation politique de l'Islande avant celle de la crise bancaire, l'auteur souligne une forte position du Parti de l'Indépendance dans la vie politique de l'État. Les résultats des élections législatives de 2007 ont confirmé ce fait. Il attire aussi l'attention sur le processus d'oligarchisation du Parti, sur le système des liens informels et des liens pathologiques entre le monde de la politique et celui des affaires. Une importante domination de quelques clans familiaux depuis des années 90., ainsi que la déréglementation et la privatisation de l'économie ont conduit au népotisme et au manque de responsabilité parmi certains politiciens et hommes d'affaires. L'expansion internationale des trois plus grandes banques islandaises (Landsbanki, 
Kaupthing et Glitnir) s'est produite sans avoir été contrôlée par l'État, et elle a conduit à une situation où à la fin de l'année 2008 les actifs de ces banques ont été 10 fois plus élevés que le PIB de l'Islande. Après la faillite de Lehman Brothers aux États-Unis, une perte de confiance sur les marchés interbancaires a provoqué une crise de liquidité, et par conséquent l'effondrement des trois banques islandaises, finalement prises en charge par l'État. La faillite d'IceSave - une banque d'épargne en ligne de Landsbanki, offrant ses services au Royaume-Uni et aux Pays-Bas - a été la plus spectaculaire. La désintégration du système bancaire a entraîné un effondrement de la coalition gouvernementale. L'Alliance socialedémocrate et le Mouvement Gauche-Vert ont remporté les élections législatives anticipées en avril 2009. Le gouvernement de centre-gauche dirigé par le Premier ministre, Mme J. Sigurðardóttir, a été formé. Le gouvernement a pris la décision importante de réorienter la politique étrangère de l'Islande et de soumettre la demande d'adhésion du pays à l'Union européenne. Il s'est ensuite concentré sur le problème de la dette résultant de la faillite des banques islandaises, puis sur la réforme de la banque centrale et des organes de supervision bancaire, ainsi que sur la mise en place d'une commission parlementaire pour examiner les causes de la crise bancaire et pour identifier les personnes responsables. Le gouvernement a décidé également de nominer un procureur spécial chargé d'enquêter sur les violations du droit lors de la privatisation du secteur bancaire et lors des mesures prises à la veille de la crise.

L'article présente l'analyse constitutionnelle et juridique des deux référendums effectués sur IceSave, après que le Président de l'Islande a opposé son veto aux lois relatives aux accords avec les créanciers - le Royaume-Uni et les Pays-Bas. En conséquence, les Islandais n’ont pas_accepté de rembourser les dettes ne leur appartenant pas, mais résultant de l'arrogance, de l'incompétence et de la cupidité des élites financières et politiques, responsables de la gestion et du contrôle du système bancaire. Cela remet en question l'adhésion future de l'Islande à l'UE. Malgré une motion de censure déposée par l'opposition, qui finalement n'a pas été adoptée, le gouvernement islandais continue de prendre des décisions difficiles sur la revitalisation du système bancaire et l'économie du pays et sur l'amélioration de l'image internationale de l'Islande. 